\title{
Vocal Materiality and Expression in Intentionally Compromised Vocal Physiology: The Cause and Effect of the Castrato Superstar Luigi Marchesi
}

\author{
TALYA BERGER
}

In the Milanese carnival of 1792, the famed castrato Luigi Marchesi created the role of Pirro in Nicola Antonio Zingarelli's opera Pirro re d'Epiro, ${ }^{1}$ As was the custom, Marchesi richly elaborated Zingarelli's original vocal part. Four performances of Marchesi singing the aria "Cara negl'occhi tuoi" and the rondo "Mi dà consiglio" were transcribed by the Bohemian composer Václav Pichl and published in 1792 at the request of a group of music dilettantes (Ms. B-BC 11550). ${ }^{2,3}$ The publication was approved by both Marchesi and Zingarelli, as was indicated on the left side of the title page: "seen by Marchesi; seen by Zingarelli." Pichl's renditions include an orchestral reduction for harp or harpsichord, and Zingarelli's original vocal part, above which are four versions of Marchesi's virtuosic ornamentations notated on separate staves. ${ }^{5}$ The title page, first page and page eleven of the Ms. B-BC 11550 are shown in Example $1 \mathrm{a}, 1 \mathrm{~b}$, and $1 \mathrm{c}$.

The title page of Pichl's publication reads:

Aria and Rondo from the Opera Pirro. Music by Nicola Zingarelli sung in Milano in the carnival of 1792 by Sig. Luigi Marchesi with Variations notated [transcribed] by Sig. Wenceslao Pichl; Engraved in the request of music dilettantes. Dedicated to his Excellency Carlo Ercole of S.R Conte di castel [...]Giussani Music engraver in $1792 .^{6}$

These unique and remarkable documents are essentially performance recordings from the eighteenth century. They represent Marchesi's voice, albeit a voice that cannot be literally heard today. Although the acoustical signal is not reproducible, the transcriptions records Marchesi's interpretive and dramatic "voice," preserving both his musical individuality and his remarkable technical agility. The transcriptions exhibit aspects of Marchesi's virtuosity and vocal acrobatics transcribed in music notation. ${ }^{7}$ Marchesi's

\footnotetext{
${ }^{1}$ The libretto was written by Giovanni de Gamerra.

${ }^{2}$ Air de Zingarelli, Ms. BC 11550 housed in Bibliothèque des Conservatoires royaux de Bruxelles.

${ }^{3}$ A recording of the aria and rondo with Marchesi's embellishments of variation 1 of Pichl's transcription was released on September 25, 2015, with Ann Hallenberg conducted by Stefano Aresi. Available on YouTube https://www.youtube.com/watch?v=61APgB4wajc

${ }^{4}$ On the left side of the title page is written: "vidit: Marchesi; vidit: Zingarelli" [seen by Marchesi; seen by Zingarelli]. I thank Stefano Aresi for bringing this to my attention.

${ }^{5}$ Pichl did not specify performance directives such as dynamics or agogics. The ornaments, when played in strict time, sound very mechanical.

6 “Aria, e rondo dell’ Opera di Pirro, Musica del Sig. Nicola Zingarelli Cantata in Milano nel Carnevale del 1792 Dal Sig. Luigi Marchesi Colle Variazioni notate Dal Sig. Venceslao Pichl; Indi alla richiesta de'Dilettanti di Musica Incise.”

${ }^{7}$ Pichl's transcriptions were first cited by Andrew V. Jones and Will Crutchfield in an article on ornamentation in Grove Dictionary. Andrew V. Jones and Will Crutchfield, "Ornamentation," The New Grove Dictionary of Opera, Grove Music Online. Oxford Music Online, Oxford University Press, accessed November 8, 2014, http://www.oxfordmusiconline.com/subscriber/article/grove/music/O903603.
} 


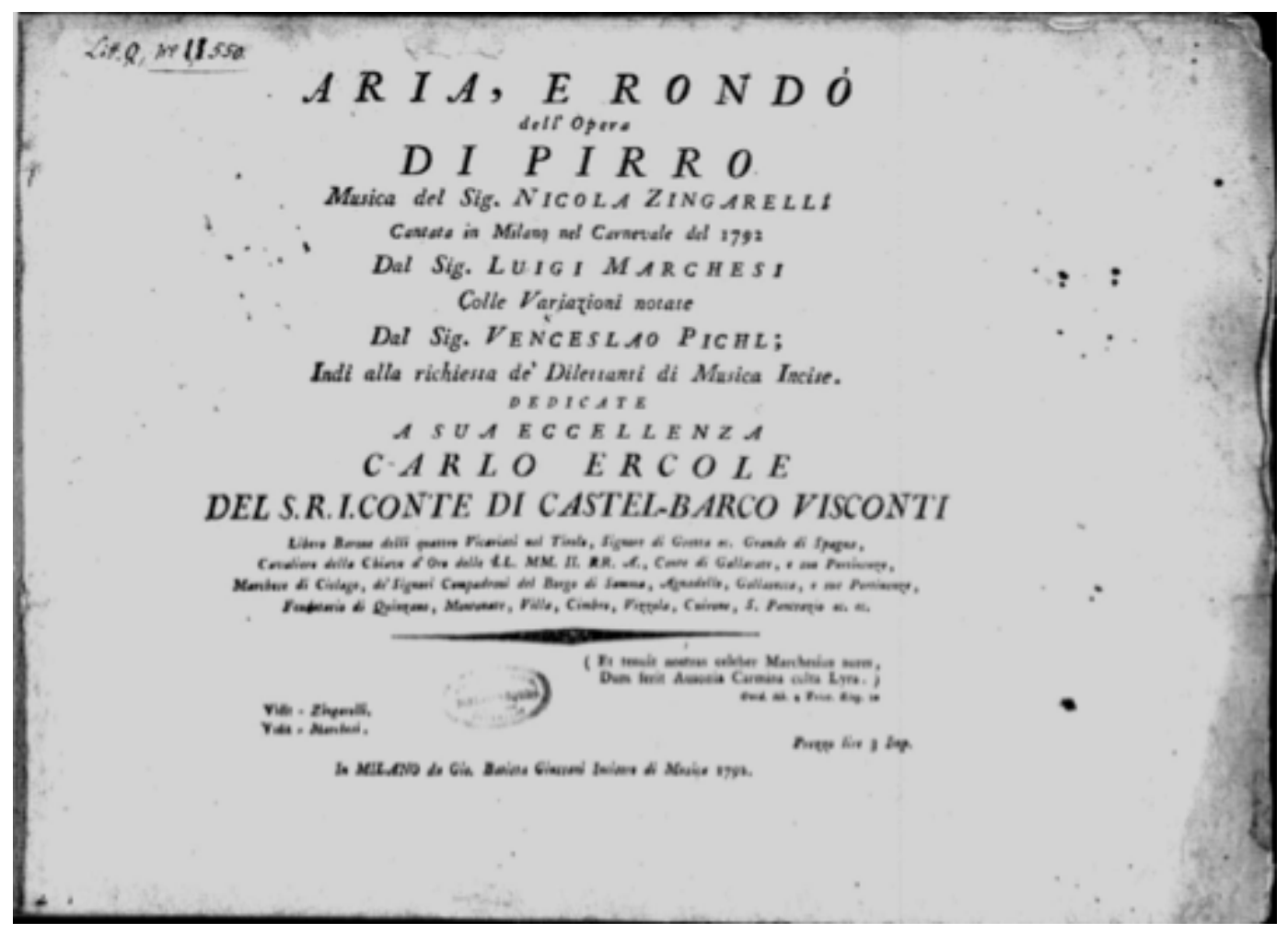

Example 1a: Title page of "Cara negl'occhi tuoi" (Ms. Bc. 11550). Reproduced by kind permission of the Bibliothèque du Conservatoire royal de Bruxelles.

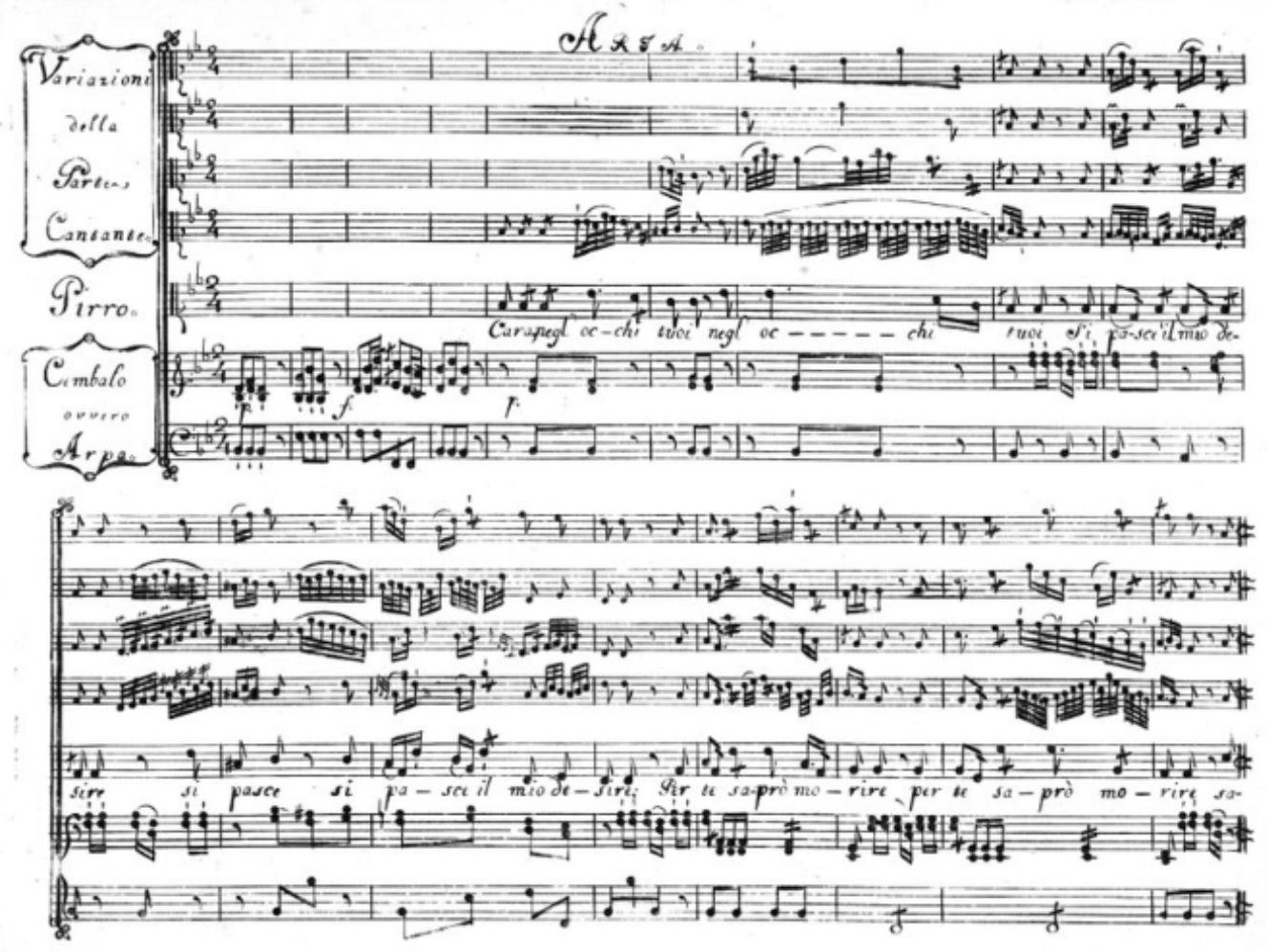

Example 1b: First page of "Cara negl'occhi tuoi" (Ms. Bc. 11550). Reproduced by kind permission of the Bibliothèque du Conservatoire royal de Bruxelles. 


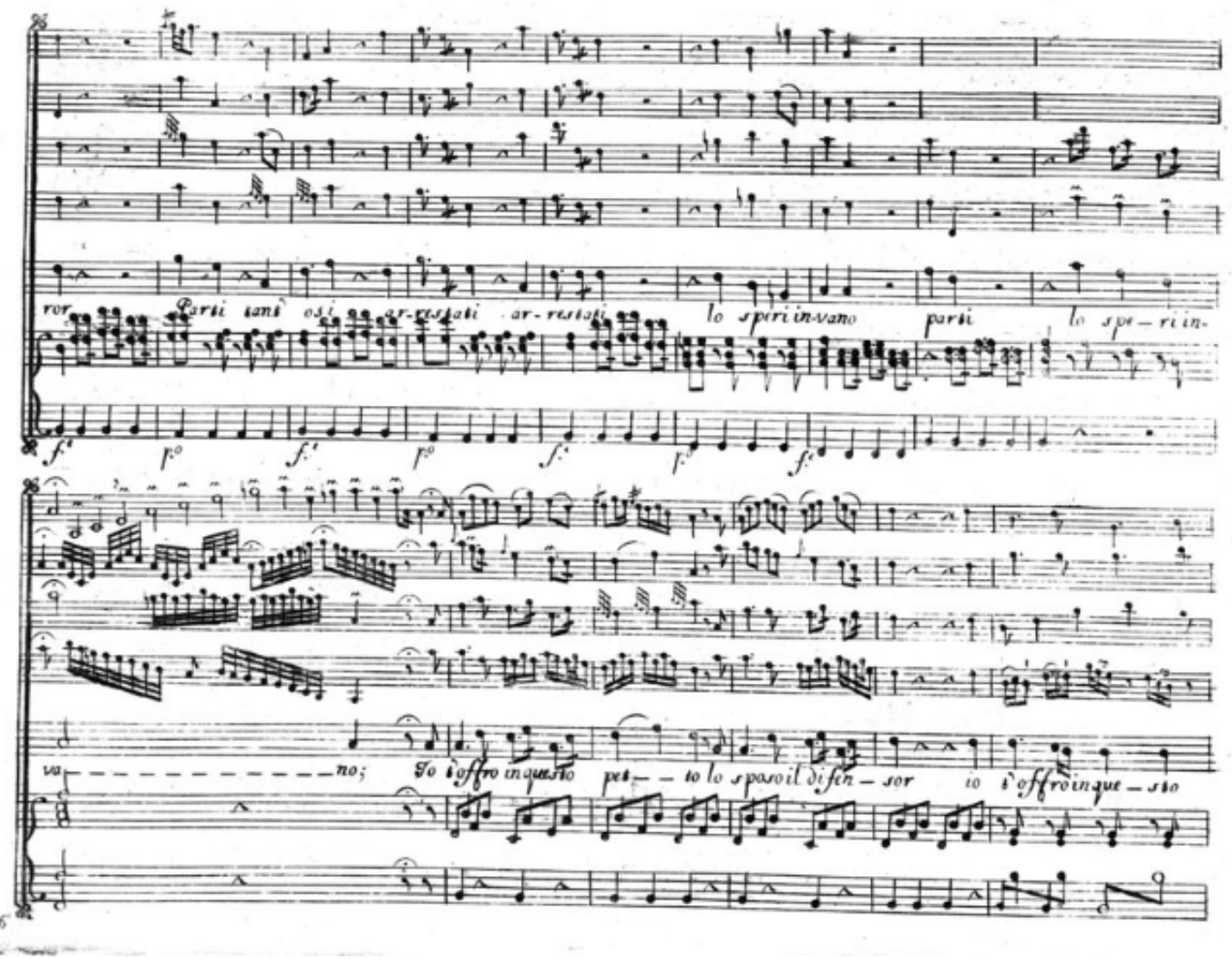

Example 1c: Page eleven of "Cara negl'occhi tuoi" (Ms. Bc. 11550). Reproduced by kind permission of the Bibliothèque du Conservatoire royal de Bruxelles.

The importance of these transcriptions is twofold: they provide a window into Marchesi's remarkable ornamentation technique and vocal agility that gave rise to his stardom, and they show the extent to which Marchesi (and other castrati) departed from the composer's original score.

Recent scholarship on castrati focuses on issues of gender and sexuality; masculinity in opera; the changing vocal voice of the hero; the evolution of the voice from castrati through travesti to contralto and tenor; and deals with historical and social perspectives. ${ }^{8}$ Several works attempt to synthetically re-create (reproduce) the vocal timbre of the castrato. ${ }^{9}$ In this paper, I concentrate on another aspect of the castrato singing style - that of virtuosity. Based on Pichl's renditions along with those by anonymous scribes, I evaluate the accuracy and veracity of period written accounts of Marchesi's performance style; I examine whether the celebrated castrato was systematic and purposeful in his selection and placement of ornaments, and evaluate the effect that the embellishments had on the music, and their subsequent influence on operatic soprano singing style; finally, I suggest that Marchesi's singing style had a profound impact on vocal music up through the present day.

\footnotetext{
${ }^{8}$ Including, among others: Martha Feldman, Reflections on Nature and Kinds (University of California Press), $2015 ;$ M. Feldman, "Denaturing the Castrato;" Naomi Adele André, Voicing Gender: Castrati, Travesti, and the Second Woman in EarlyNineteenth-Century Italian Opera, 2006; Angus Heriot's The Castrati in Opera, 1956, reprinted in 1974; Thomas Alan King, The Gendering of Men, 1600-1750, Vol. 2, 2008; Patrick Barbier, The World of the Castrati, 1996; and Masculinity in Opera, ed. by Philip Purvis, 2013.

${ }^{9}$ Bennett, G., Rodet, X., "Synthesis of the Singing Voice", in Current Directions in Computer Music Research, ed. M.V. Mathews \& J.R. Pierce, MIT Press, 1989. P. Depalle, G. García \& X. Rodet, “A virtual castrato (!?),” International Computer Music Conference, Aarhus, Denmark, 1994.
} 


\section{Background}

Luigi Marchesi was among the most praised Italian castrati at the end of the eighteenth century. He was known for his vocal agility, celebrated for the color of his voice and expressive singing, and renowned for his improvisational prowess. He was also notorious for excessively embellishing his parts. ${ }^{10}$ Marchesi's theatrical career began in 1773 in Teatro delle Dame in Rome, singing the female role in Marcello da Capua's comic opera La contessina, after which he sang only heroic male roles in serious opera (opera seria). He performed throughout Italy and the European continent. Among his admirers was the Empress Marie Therese who performed in many private concerts with him. ${ }^{11}$

Composers wrote especially for Marchesi, showcasing his voice either with complex written embellishments, or by leaving the score simple and austere, providing him with ample opportunity to add his own embellishments. The complex vocal part of Domenico Cimarosa's aria of Megacle, "Superbo di me stesso," from Act I of the opera L'Olimpiade, is an example of a virtuosic vocal part composed to suit Marchesi's vocal agility (above which, undoubtedly, Marchesi added his own). "Cara negl'occhi tuoi" and Cherubini's "Quanto è fiero il mio tormento" are examples of simple vocal parts inviting embroideries. Among the composers who wrote with his voice in mind were: Josef Mysliveček, Antonio Soler, Giuseppe Bianchi, Giuseppe Sarti, Luigi Cherubini, Simon Mayr, Nicola Zingarelli, and Domenico Cimarosa. Marchesi performed the role of Pirro over six consecutive seasons from 1792 to $1798 .{ }^{12}$

\section{The Effect of Castration on the Physiology of the Vocal Tracts}

Castration for the purpose of preserving the voice of a juvenile boy into adulthood was performed in Italy from the late sixteenth century until 1865, when it was outlawed in Europe. The objective was to create adult male soprano singers for the church and for the opera seria stage.

The physiology of the vocal tract includes the larynx (also called the voice- or music- box), which houses the vocal folds (or cords). The vocal folds contain two parts: a firm cartilaginous part, and a thin, flexible membranous part that vibrates during phonation. Up to the onset of puberty the length of the vocal folds is about $10 \mathrm{~mm}$ long. Until the age of 10 years old there is no significant difference in the size of the folds between males and females. During puberty, the secretion of the male hormone testosterone causes the larynx to descend, and the vocal folds to grow in length and thickness. These changes affect the range of fundamental pitches and the timbre of the voice. The average size of the vocal folds in an adult male is between $14.5-17.0 \mathrm{~mm} .{ }^{13}$ In adult males castrated before puberty, the vocal folds remain at the size of a juvenile boy, which are smaller than those of an adult woman. ${ }^{14}$ This in part, perhaps, explains why the timbre of a castrato's voice was depicted as being more delicate and sweeter than that of a woman.

Castration did not affect the growth of the sinus, pharynx, oral cavity, and thorax. According to period accounts, castrati grew to be abnormally tall, and had a large thorax with a very broad rib cage.

\footnotetext{
${ }^{10}$ The side effects of castration didn't have a profound effect on his looks, and he was handsome and slim, which undoubtedly contributed to his popularity.

${ }^{11}$ John Rice, Empress Marie Therese and Music at the Viennese Court, 1792-1807 (Cambridge University Press, 2007 ), 71.

${ }^{12}$ Simon Mayr composed an aria strikingly absent of virtuosity for the prima donna Teresa Bertinotti. Its restraint was assurance that she would not outshine the aging Marchesi.

${ }^{13}$ Joel C. Kahane, "Growth of the Human Prepubertal and Pubertal Larynx," Fournal of Speech and Hearing Research, vol.5, no.3 (1982), 446.

${ }^{14}$ Enid Rhodes Peschel and Richard E. Peschel, "Medical Insights into the Castrati in Opera," American Scientist (NovemberDecember, 1987), 579-80.
} 
Thus, the castrato voice retained the range and color of a juvenile boy, however, with the vocal power, resonance, and intensity of an adult male.

This compromised vocal physiology enabled the castrati to sing large intervallic skips swiftly, and to perform complex and highly ornamented passages with ease and with extreme breath control. ${ }^{15}$ Music written for the castrati exhibited these technical capabilities. The aria "Son qual nave, che agitate" was composed by Riccardo Broschi (1698-1756) in order to showcase the vocal agility of Broschi's brother Farinelli (1705-1782). ${ }^{16}$ The aria is an example of a highly ornamented and technically challenging vocal part. ${ }^{17}$ On March 30, 1753, Farinelli presented Empress Maria Theresa the music with his added embellishments annotated in red on the score. Farinelli's embellishments look modest compared with those by Marchesi. The cadenzas in mm. 20 and 75 of Cherubini's rondo "Quanto è fiero il mio tormento," shown in examples $2 \mathrm{a}$ and $2 \mathrm{~b}$ below, demonstrate the extent of Marchesi's technical ability.

Condemnation and denunciation of castration and castrati's singing style by humanists, philosophers, and religious figures was widespread in the eighteenth century (i.e., Francesco Albergati Capacelli (1728-1804), Charles de Blainville, 1740, Giovanni Antonio Bianchi 1753, Francesco Algarotti 1755, Giuseppe Parini, Rousseau, De La Lena, Voltaire, Pietro Verri, Metastasio, and others). ${ }^{18}$ Castration was perceived as an act that disfigured nature, a cruel practice cultivated by the decadent and aristocratic society that went against ethical and religious values and philosophical thoughts of the Enlightenment. ${ }^{19}$ However, despite the denunciation of castrati, Marchesi maintained celebrity status - analogous to today's "rock star" idols. As a testament to his notoriety women admirers wore medallions with his portrait around their neck and wrist, and a group of women in Milan embroidered his abbreviated name on a sash. ${ }^{20}$ Another mark of his popularity is the number of manuscripts extant of Pirro's aria, containing embellishments attributed to Marchesi. ${ }^{21}$ Moreover, as noted previously, Pichl's publication came about at the request of the musical dilettanti who desired to sing like "the star." 22 If not for them, these rare records of Marchesi's performances would not have been created.

Remarkably, Pichl's transcriptions found their way into a fortepiano method book from 1825 entitled Cours complet pour l'enseignement du forté piano by the virtuosic French pianist, and piano teacher Hélène Montgeroult (1764-1836), who incorporated Marchesi's embellishments to demonstrate how to imitate the singing voice on the piano, and how to apply ornamentations. ${ }^{23}$

\footnotetext{
${ }^{15}$ It is plausible that castrati were capable of producing singer's formant, a vocal technique sopranos do not typically acquire. (See Sundberg, J. et al, "Sopranos with a Singer's Formant, Historical and Acoustical Aspects of Castrato Singers," TMHQPSR, KTH (2007), 2.

${ }^{16}$ His birth name was Carlo Broschi.

${ }^{17}$ The aria with orchestral reduction for piano was published by F. Haböck in 1923 in Vienna in Die Gesangskunst der Kastraten, Wien, Universal-Edition (1923), 171-187. The original manuscript is housed in Vienna at the Österreichische Nationalbibliothek (Hs. 19111). On March 30, 1753, Farinelli presented the Empress Maria Theresa the score with his added embellishments annotated in red on the score.

${ }^{18}$ Martha Feldman, "Denaturing the Castrati," The Opera Quarterly, vol. 24, no. 3-4 (2008), 178-9.

${ }^{19}$ Ibid.

${ }^{20}$ Richard Somerset-Ward, Angels and Monsters: Male and Female Sopranos in the Story of Opera, 1600-1900 (New Haven: Yale University Press, 2004), 85.

${ }^{21}$ I list the manuscripts on pp. 10-12.

${ }^{22}$ Stefano Aresi, in a personal communication, suggested that Pichl's publication of Pirro's aria is a commemorative score.

${ }^{23}$ Hélène Montgeroult, Cours complet pour l'enseignement du forté piano (Paris, 1825). In Montgeroult's edition Pichl's name is not mentioned.
} 


\section{On Transcription and Annotations}

The advent of acoustic recording along with mechanically preserved piano performances (e.g., in piano rolls) toward the close of the nineteenth century fostered a rich body of recent musicological research in performance analysis. Notated transcriptions of performances and annotations predating acoustical recordings expand the field of historical performance practice by offering glimpses at practices that have no acoustic documentation. Transcriptions and annotations describe, and to one degree of specificity or another, represent a record of the actual performance of a given piece. To this end, they provide valuable information on how the piece was performed, and adapted to a specific performance. In rare instances, as in the case of Pichl's renditions, constituting the "fully-clothed" musical product through transcription. As Dennis Libby notes “The singer's contribution to an aria in performance is to be regarded not as post-compositional but as the final stage in the act of the composition itself. It follows that it was not the composer's score but the performed music that embodied the finished work of art, one that was both fluid-varying with each realization—and ephemeral, not directly recoverable." ${ }^{24}$

Documentation of a musical performance by written transcription most closely approaches that of acoustical or mechanical recordings, when the transcription is recorded by a skilled audience member who witnessed the performance (either taking dictation in quasi-real-time or committing to memory and notating the performance afterwards). The validity and scholarly value of such a recorded document is, of course, enhanced when the identity and credibility of the "transcriber" is known, as is the case in the Marchesi transcriptions by Pichl.

The technical facility to notate such complex florid lines in real time required both considerable skill, and familiarity with Marchesi's habits and tastes in embellishment. Pichl was a leading European composer, violinist, Kapellmeister, music director, and music historian. From 1770 to 1796 he served as the principal violinist and music director of the orchestra of the Archduke Ferdinand d'Este in Milan. He traveled with the court to Mantua where he had numerous opportunities to meet, hear, and possibly perform with Marchesi. Pichl composed over 700 compositions, including secular and sacred compositions, for orchestra and chamber ensembles. Many of his stage works are currently considered lost. $^{25}$

\section{The Renditions}

Pichl's transcription of Zingarelli's aria, "Cara negl'occhi," and the rondo "Chi mi dà consiglio" were published in 1792 with harpsichord/harp orchestral reduction (Ms. B- Bc -11550). An advertisement inviting musical amateurs to take notice of this publication appeared in Giornale enciclopedico di Milano in 1792. ${ }^{26}$ The notice reads:

A notice to music dilettantes

Sig. Gio Battista Giussani is putting under the press [published] two pieces of music from the opera Pirro by Sig. Nicola Zingarelli, the aria from the second act Cara Negl'occhi tuoi, and

\footnotetext{
${ }^{24}$ Dennis Libby, "Italy: Two Opera Centers," in The Classical Era, ed. N. Zaslaw (Prentice-Hall, 1989$), 16$.

${ }^{25}$ Milan Poštolka. "Pichl, Václav," Grove Music Online. Oxford Music Online (Oxford University Press), accessed August 5, 2013, http://www.oxfordmusiconline.com/subscriber/article/grove/music/21686.

${ }^{26}$ Giornale enciclopedico di Milano, 15. X. 1792, 252, In Bascialli Francesca, Opera Comica e Opéra-Comique Al Teatro Arciducale Di Monza (1778-1795) (Lucca: Libreria musicale italiana, 2002), 59.
} 
the Rondo from the same opera with variations performed excellently by Sig. Luigi Marchesi, and transcribed by Sig. Wenceslao Pichl, the dilettanti are therefore invited $[\ldots]^{27}$

There are four additional undated manuscripts containing Marchesi's embellishments of the same aria by an unidentified scribe that display similar ornamentations as in Pichl's publication:

1. Ms. 628.A.12 is housed in the Biblioteca del Conservatorio di musica S. Pietro a Majella in Napoli. The title page reads: "Scena dell'Aria di Zingarelli nel Pirro Distinta colle variazione che soleano farsi dal celebre cantore Marchesi." [With variations which were usually made by Marchesi.]

Unlike Pichl's transcription, this manuscript contains a chamber orchestral accompaniment, and has modest embellishments transcribed by an anonymous hand. There are similarities between the embellishments to those notated by Pichl. Therefore, it is likely that the embellishments were based on Marchesi's performance. It is conceivable that it served as the score in a private concert.

2. Ms. 628.A.13 in the Biblioteca del Conservatorio di musica S. Pietro a Majella - Napoli - NA, is a handwritten copy by anonymous scribe of the aria "Cara negl' occhi tuoi, " with embellishments attributed to Marchesi. The title page boasts Marchesi's reputation as a singer and his embellishments. The title page reads: "Cara negl' occhi tuoi Aria del Celebre Maestro Sig. ${ }^{r}$ Zingarelli, Fatta nel Pirro, e Cantata dal Grande Cantore Sig. ${ }^{r}$ Luigi Marchesi, colle più belle variazioni che solitamente. si faceano da recita in recita." [...] with beautiful variations that were made in each performance. (Based on the title page it is plausible that this manuscript, like Pichl's, was aimed at those who wanted to "sing like the star.")

3. Ms. MI0344 in Biblioteca del Conservatorio statale di musica Giuseppe Verdi in Milano is a handwritten copy by anonymous scribe, however identifies the transcriber as Sig. ${ }^{\text {r }}$ Raffaello Pagliari Napolitano. The title page reads "Scena dell'Aria della Marcia Con le Variazioni del Celebre Sig ${ }^{r}$ Luigi Marchesi nell'Opera di Pirro Composta del Sig. ${ }^{r}$ Maestro Nicola Zingarelli Dedotte e Trascritte Dal Sig. Raffaello Pagliari Napolitano.”

This manuscript contains orchestral accompaniment with similar embellishments as notated by Pichl, suggesting that this rendition was based on Marchesi's singing (or taken from Pichl's transcriptions).

4. MS Add. 32676 Vol. III, f.132, housed in The British Library, is an undated compilation of vocal pieces by many composers. The manuscript was likely copied in the late eighteenth century by an unidentified copyist, and could have plausibly served as an eighteenth century anthology for performances_a "gig book" of sorts. It contains Zingarelli's aria "Cara negl'occhi tuoi" and the rondo "Chi mi dà consiglio" with chamber orchestral accompaniment. The manuscript includes three variations attributed to Marchesi that are almost exact reproductions of those notated by Pichl. It is, thus, likely that it was copied from Pichl's publication.

It is likely that Pichl also transcribed Marchesi's performances of Luigi Cherubini's rondo "Quanto è fiero il mio tormento" from the opera "Nell'Alessandro Nelle Indie." (Bnf Musique D 17319). ${ }^{28}$ The undated manuscript, copied by an anonymous hand, contains Cherubini's original line, above which there are fifteen variations by Marchesi with the original orchestral accompaniment. According to the title page, Pichl paraphrased Marchesi's renditions in a performance that took place in Mantua in 1784. The title page

\footnotetext{
27 “Avviso ai dilettanti di musica: “Avendo il Sig. Gio Battista Giussani messo sotto i torchi due pezzi di musica dell'opera Pirro composti dal Sig. Nicola Zingarelli, cioè l'aria del secondo atto Cara negl'occhi tuoi, ed il Rondò d'essa opera colle variazioni egregiamente eseguite dal Sig. Luigi Marchesi, e notate dal Sig. Wenceslao Pichl, restano perciò invitati i Signori dilettanti $[\ldots]$ ”

${ }^{28}$ A recording of the rondo with Marchesi's embellishments in variation 1 of Pichl's transcription was released on September 25, 2015 with Ann Hallenberg and conducted by Stefano Aresi. Available on YouTube: https://www.youtube.com/watch?v=In54APcCpP0.
} 
reads: ${ }^{29}$

Rondo // Musica del Sig Luigi Cherubini // sung by Sig. Luigi Marchesi // Put in paraphrase [paraphrased] by Sig. ${ }^{\mathrm{r}}$ Wenceslao Pichl while the abovementioned Marchesi was performing it in Mantua in the Spring of $1784 .^{30}$

Given the connotation of "paraphrase" is a diversion from, or variation of another's idea, it is important to disambiguate the term as used in the title. Does paraphrase here refer to Pichl's method of recording (i.e., paraphrasing) of Marchesi's vocalizations? Or does it refer to Marchesi's paraphrases (i.e., as a noun), referring to his elaborated variations of Zingarelli's schematic aria?

Since Pichl's real-time transcription presumably retained as close an account of Marchesi's performances as possible without addition or editorial changes, this document constitutes a recording by Pichl of Marchesi's paraphrases of Zingarelli's tune.

Another title on the cover indicates that the manuscript was published in 1794 in Journal d'ariettes italiennes, designates the score as a vocal etude. This, however, seems implausible given the accompanying orchestral setting. The title page reads:

Italian aria by Cherubini // with embroidered ornaments by the celebrated Marchesi // a singing etude. ${ }^{31}$

The Österreichische Nationalbibliothek in Vienna holds another handwritten manuscript of "Quanto è fiero il mio tormento" containing fourteen variations by Marchesi. The manuscript, first cited by Robert Haas in 1931 (Ms Mus. Hs. 3920), is an almost exact replica of the manuscript in Paris, although, the title page omits Pichl's name as the transcriber. There are some differences between the Paris and Vienna manuscripts. The Vienna manuscript contains two more elaborated lines in mm. 27-29 than the one in Paris. The title page reads: "Composed in Mantua in the spring of 1784 by Sig. Cherubini. Was performed and varied by Luigi Marchesi." 32

The rondo "Rendi, o cara, il Prence amato" by Giuseppe Sarti, containing undated transcriptions of Marchesi's embellishments by an unidentified hand, is the third piece. The manuscript comprises one variation with orchestral accompaniment. ${ }^{33}$ Damien Colas argues the transcription was made after the performance. $^{34}$ (This aria is discussed at length by Colas, and is not examined here. $)^{35}$

\footnotetext{
29 "Rondo //Musica del Sig. ${ }^{\mathrm{r}}$ Luigi Cherubini //Cantato Dal Sig. ${ }^{\mathrm{r}}$ Luigi Marchesi//Messo in Parafrasi dal Sig. ${ }^{\mathrm{r}}$ Wenceslao Pichl// Mentre che il sudetto Sig. ${ }^{\mathrm{r}}$ Marchesi lo eseguiva// a Mantova la Primavera 1784." The title page of Ms. Bnf Musique D17319. The manuscript can be obtained at: http://gallica.bnf.fr/ark:/12148/btv1b52501474w.r=Marchesi+quanto+e+.langEN.

${ }^{30}$ Translated to English by Berger.

31 "Air italien de Mr. Chérubini // Avec les Broderies ornemens de la composition du celebre Marchesi // pour l'étude du chant.”

32 “Composto á Mantua per l'opera di primavera dell'anno 1784. Dal Sig. Cherubini. Eseguito e variato dal Luigi Marchesi." Title page can be viewed at http://gallica.bnf.fr/ark:/12148/btvlb52501474w.r=luigi\%20marchesi?rk=42918;4.

${ }_{33}$ The title page reads: "Rondo Rendi, o cara, il Prence amato con recitativo del Sig. Giuseppe Sarti per il Sig ${ }^{r}$ Luigi Marchesi nell "Olimpiade in Roma nel nobillisimo Teatro delle Dame presso Antonio Zatta e figli, Venezia, [1784]."

${ }^{34}$ Damien Colas notes the similarities between the themes of Cherubini's aria "Quanto è fiero il mio tormento" and Sarti's "Rendi, o cara il Prence amato." Colas Damienand Alessandro di Profilio, "Le rondò ‘Rendi, o cara, il Prence amato’ de Sarti et les ornements de Marchesi," in D’une scène à l'autre, l'opéra italien en Europe: Les pérégrinations d'un genre (Mardaga, Wayre, 2009), 167.

${ }^{35}$ Colas, “Le rondò 'Rendi, o cara, il Prence amato' de Sarti et les ornements de Marchesi,” 157-88.
} 


\section{Period Accounts on Castrati's Singing Style, and in Particular, of Marchesi's Vocal Style}

In his satirical parody Il Teatro alla Moda (1720), Benedetto Marcello describes the state of the opera during his times. He depicts the virtuoso castrato as being concerned with vocal acrobatics such as flashing out complex passage works, trills, appoggiaturas and chains of cadenzas, rather than paying attention to the meaning of the meaning of the text, and pronouncing it correctly.

To become a virtuoso singer one need not to be able to read or write, or to pronounce correctly vowels and diphthongs, nor does he have to understand the text. He must be expert, however, at disregarding the sense and at mixing up letters and syllables in order to show off flashy passages, trills, appoggiaturas, endless cadenzas, etc." ${ }^{36}$

Critical views of the singing style of castrati persist through the end of the century. In 1773 the architectural historian Francesco Milizia depicted their singing in Del Teatro as:

Most [castrati ... split] the voice [squartare la voce], leap from note to note, shake, [and make] arpeggios. And with passaggi, trills, caprices, arpeggios, little fragments [spezzature] and leaps [volate], [they] make music florid and choked with ornament, disfiguring any beauty ... in this guise ... their arias resemble the ladies of France. ${ }^{37}$

Numerous period accounts describing Marchesi's singing style list features and faults of his voice and of his embellishment style. Charles Burney admired his singing and improvisational skills:

The Giulio Sabino of Sarti was the first opera in which Marchesi performed on our stage. The elegant and beautiful music of this drama did not please so much here as it ought, and had done in other parts of Europe (b.). Several of the songs indeed had been previously sung here at concerts, and did not appear new. Marchesi's style of singing is not only elegant and refined to an uncommon degree, but often grand and full of dignity, particularly in his recitative and occasional low notes. His variety of embellishments and facility of running extempore divisions are truly marvelous. Many of his graces are new, elegant and of his own invention; and he must have studied with intense application to enable himself to execute the divisions, and running shakes from the bottom of his compass to the top, even in rapid series of half notes. ${ }^{38}$

A review in the Gazette, of his performance in Juilio Sabino at King's Theater in 1788 describes the color of Marchesi's voice in the low and high ranges and his natural transitions from the low to high range and vice-versa. However, he found fault with the excessive embellishments.

Inquisitor fine, particularly his lowest tones, from which he makes the most beautiful transitions to the highest notes. The nasal intonation so frequently in the Italian school... is a fault from which Marchesi is totally free. If he has a fault, it is that he embellishes with too many graces. ${ }^{39}$

Another review, often quoted in modern writings, is by the Milanese social economist and scholar,

\footnotetext{
${ }^{36}$ Marcello, Benedetto, Il Teatro Alla Moda: O Sia Metodo sicuro, e sacile per ben comporre, ed eseguire L'Opere Italiane in musica all'uso moderno[...] Stampato Ne' Borghi Di Belisania Per Aldiviva Licante; All' Insegna Dell' Orso In Peata. Si Vende Nella Strada Del Corallo Alla Porta Del Palazzo D'orlando E Si Ristamperà Ogn'Anno Connuova Aggiunta. [Venezia, .1720], 23. Il Teatro alla Moda, was translated by R.G Pauly, in The Musical Quarterly, vol. 34, no. 1 (July, 1948), 388.

${ }^{37}$ Francesco Milizia, Del Teatro (Venice, Giambattista Pasquali, 1773), 53, translated by M. Feldman in "Denaturing the Castrato," 187.

${ }^{38}$ Charles Burney, A General History of Music, vol. 4 (London: 1789), 530.

39 Theodore Fenner, Opera in London: Views of the Press, 1785-1830 (Southern Illinois University Press, 1994$), 163$.
} 
Pietro Verri (1728-1797), who wrote in a letter to his brother Alessandro of his ambivalence regarding Marchesi's singing style-lauding the beauty of his voice and vocal agility, yet critical of his inability to move the heart.

His voice is most beautiful, sonorous, the same in every part of his range...his intonation is faultless and he control his voice as one would a violin. It can produce a clear trill rising up six seven tones in succession without interruption [...] He supports his voice and fills the theatre $[\ldots]$ is passionate... tender [...] He has everything except, I believe, that feeling which knows how to touch one's soul. ${ }^{40}$

Verri's critical opinion of the aesthetic value of Marchesi's singing indicates that, while few could possibly be unimpressed by Marchesi's technical agility, not all considered his performances as meaningful artistic interpretations. Zingarelli's presumably veracious transcriptions, while agnostic to artistic merit, document the potential for such divided opinions.

A more detailed description of Marchesi's vocal acrobatics was described in an anonymous pamphlet, Lodi caratteristiche del celebre cantore signor Luigi Marchesi (1781). ${ }^{41}$ The author lists Marchesi's technical ability of performing with ease: messo le voce, sequence of trills in one breath, large skips, complex passages with chromatic semitones, sbalzo in octaves, arpeggios and complex passage work, moving seamlessly between registers and a large vocal range.

Among the most singular things that he exhibits in his passages passaggi can be observed in the sixteenth notes a beat [when he divides the beat into four sixteenth notes], of which the first of each four he vibrates, blurring over the other three. At times he insinuates hints at a stepwise melody through the leap of a seventh in a different octave that in reality is a continuous changing of octaves in the seventh, and at times they combine the stepwise melody with arpeggiation, skips and stepwise movement, often at a pace not heard off pace, that one cannot tell how many notes he has sung, despite delivering them so clearly. ${ }^{42}$

The renditions substantiate Marcello's and Milizia's exemplars of the traits of castrati, and in particular, of Marchesi's singing style. His extraordinary vocal agility comes across in the three consecutive cadenzas of Cherubini's "Quanto è fiero il mio tormento" (m. 20 shown in Example 2b, mm. 23-24 shown in Example 8, and m. 26 Ms p. 5), saving the most technically challenging elaboration for the climactic third cadenza m. 75-77, shown in Example 2a. These cadenzas show his 'bag of tricks' as described in Lodi caratteristiche. (The score speaks for itself.) Secondly, the renditions verify that Marchesi packed the score with ornaments to the extent that the music sounds at certain places grotesque, "choked with ornament, disfiguring any beauty." (See examples 2 through 9.)

The almost skeletal simplicity of both Zingarelli's and Cherubini's original scores suggest that the composed music was merely a vehicle for the performer's elaboration. Despite the highly emotive text, Zingarelli's score features simple, diatonic harmony. The harmonic language, save for a brief excursion,

\footnotetext{
${ }^{40}$ Pietro Verri was a Milanese social economist and a scholar. His main contribution was in tax reforms. The quotation comes from a letter Pietro wrote to Alessandro on February 19, 1780. Emanuele Greppi and Alessandro Giulini, Pietro Verri's correspondence with his brother Alessandro (Cogliati 1910-42), vol. 11. It was quoted (and presumably translated by Sven

Hansell) in Sven Hansell. "Marchesi, Luigi." Grove Music Online. Oxford Music Online. Oxford University Press, accessed September 10, 2014, http://www.oxfordmusiconline.com/subscriber/article/grove/music/17732.

${ }^{41}$ Lodi caratteristiche del celebre cantore signor Luigi Marchesi,Vincenzo Pazzini Carli e figli, 1781.

42 "Tra le cose più singolari che ei eseguisce nei suoi passaggi si osserva che in sedici semicrome d'una Battuta la prima delle quatro d'ogni tempo la vibra, sfumando le alter tre. Alle volte accenna un andamento di grado che in realtà è un continuo sbalzo d'ottava in settima ed alle volte combina l'andamento ora disalto, ora d'arpeggio, ora di grado, e spesso con una velocità non più udita, che non lasci adistingure il numero delle voci che tocca, quantunque sieno sensibilissime.” Translated to English by Alessandra Aquilanti.
} 
merely alternates tonic and dominant chords with an occasional pedal IV6/4. The orchestral texture is likewise simple, avoiding any clear reinforcement and articulation of the text. Similarly, the melodic lines are plain, even lacking in character, and are fragmented with rests and large skips. The banality of Zingarelli's score throws the entire focus on the singer's vocal acrobatics and remains entirely subservient to his showmanship. The aria and rondo provided Marchesi an anchor to which he could return.

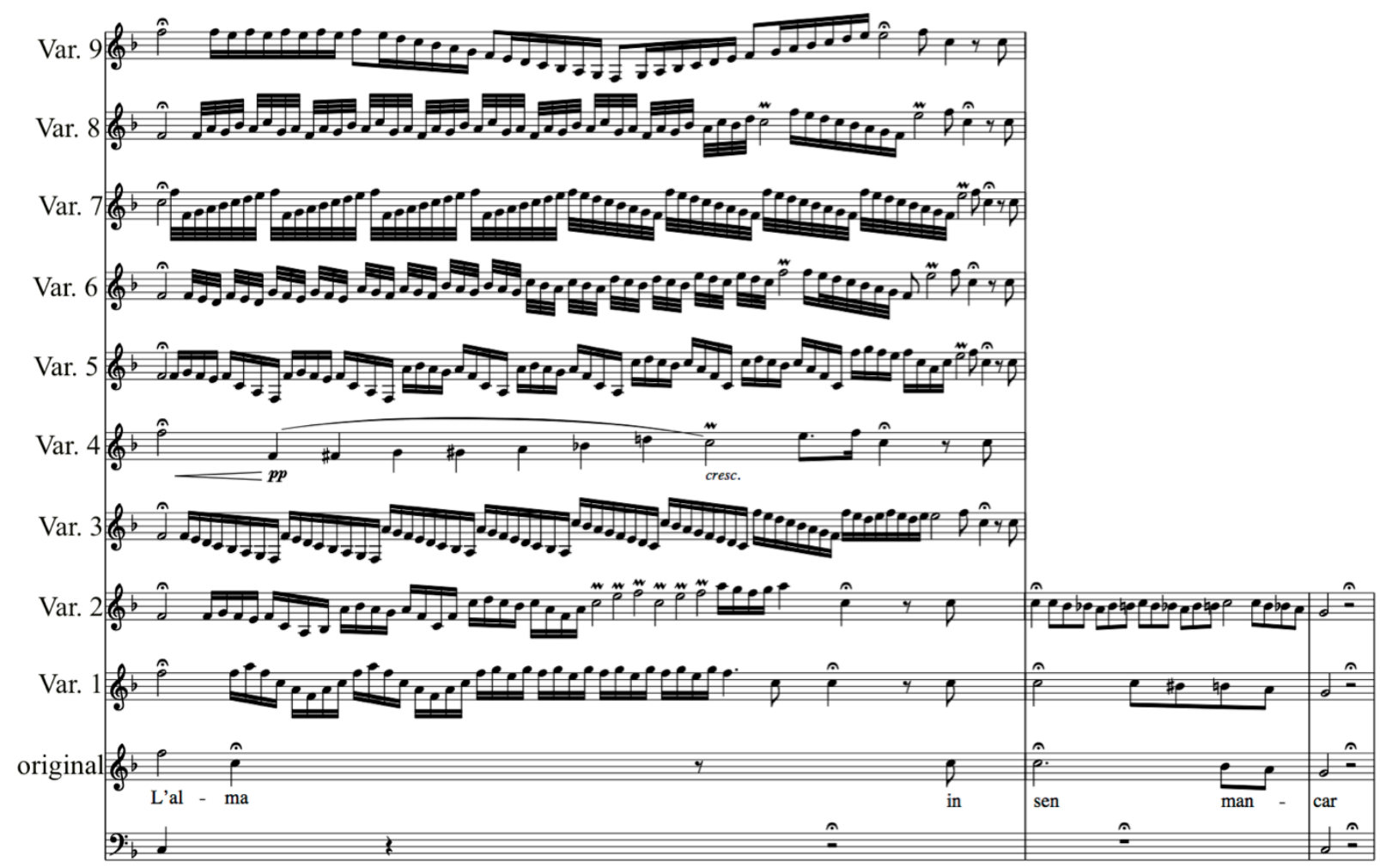

Example 2a: Marchesi's cadenza in mm 75-77 of Cherubini's Rondo "Quanto è fiero il mio tormento" Var. 2 followed by Var. 3. The embellishments display Marchesi's "bag of tricks." Performed by Ann Hallenberg with Stile Galante, conducted by Stefano Aresi. ${ }^{43}$

Listen at: http://dx.doi.org/10.3998/mp.9460447.0010.203

"Lodi caratteristiche" describes Marchesi's range as encompassing three vocal ranges: tenor, contralto, and acute soprano: ${ }^{44}$ "His voice is intense in the soprano range, robust in the contralto, and singing in the tenor voice." 45

This wide vocal range is presented in measure 20 of "Quanto è fiero il mio tormento," shown in Example $2 b$, where the range extends from $\mathrm{G}^{3}$ to $\mathrm{Bb}^{5} .\left(\mathrm{G}^{3}\right.$ in variation 1, and $\mathrm{Bb}^{5}$ in variation 6.)

\footnotetext{
${ }^{43}$ Ann Hallenberg, Arias for Luigi Marchesi, Stile Galante and Stefani Aresi (Glossa, Sept. 2015).

${ }^{44}$ Colas, "Le Rondò "Rendi, o cara, il Prence amato" de Sarti et les ornements de Marchesi," 164.

45 "l'acutissima di soprano, quella di mezzo di contralto robustissima, e la piu virile e toccante di tenore [...] Lodi caratteristiche del celebre cantore signor Luigi Marchesi, p. IV.
} 


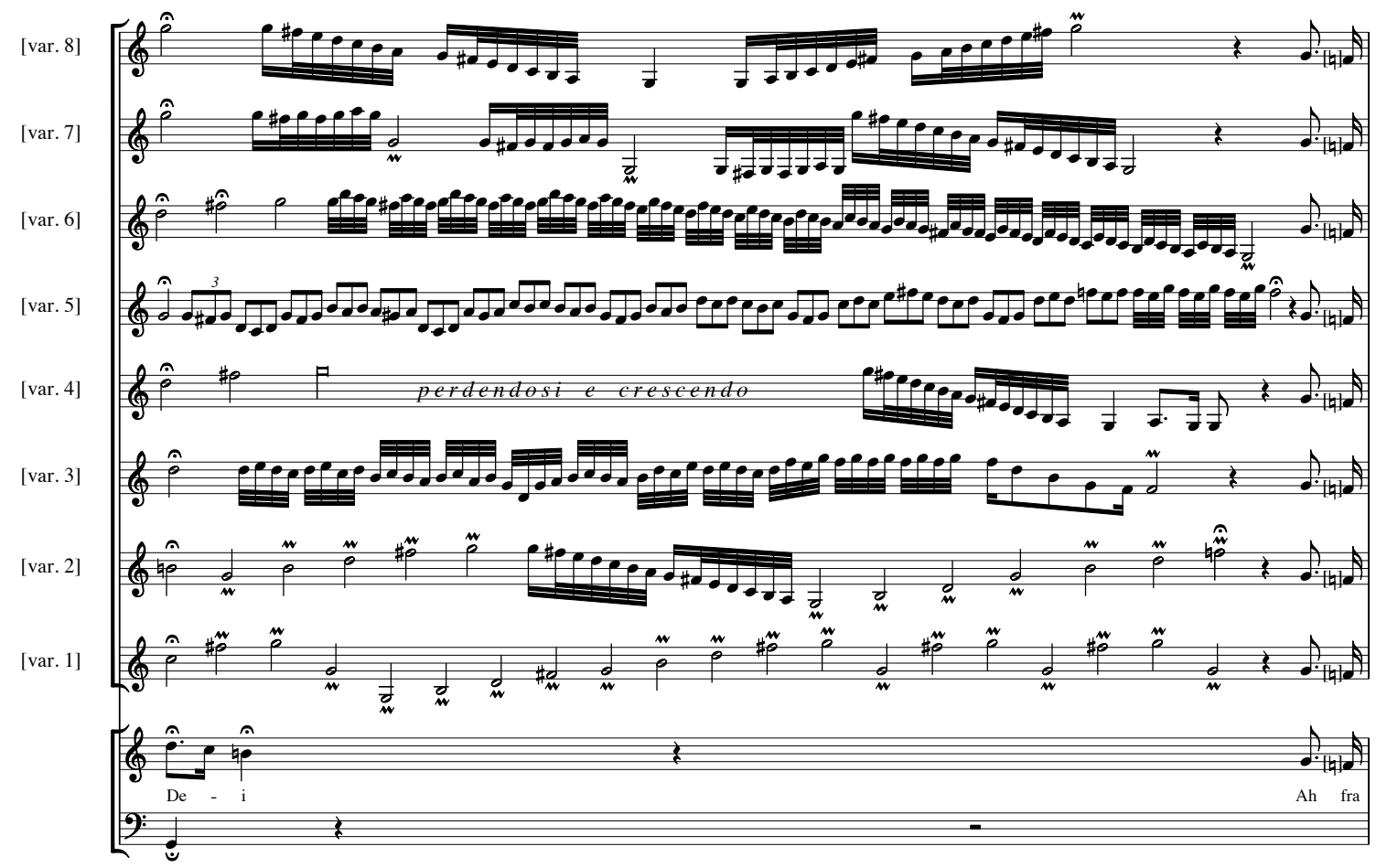

Example 2b: Var. 2 followed by Var. 3 of the cadenza in m. 20 of Cherubini's Rondo "Quanto è fiero il mio tormento." Performed by Ann Hallenberg with Stile Galante, conducted by Stefano Aresi

Listen at: http://dx.doi.org/10.3998/mp.9460447.0010.203

\section{Is There a Method to His Madness?}

The excessive flamboyance and exuberant qualities of Marchesi's embellishments in the cadenzas of Cherubini's rondo scream out of the page. While, at first glance, these excesses may appear as sheer madness, there is, in fact, a method to this madness. (Consider examples $2 \mathrm{a}$ and $2 \mathrm{~b}$.) Each of the performances elaborates the score with a distinct character-each a variation on the theme. Notably, Pichl's transcriptions (as well as all the other manuscripts), designated Marchesi's elaborated part as Variazione, rather than embellishments. The slow sections are embellished from start to end, while the fast sections are less decorated, often adhering to a single melodic idea.

A comparison of Marchesi's ornamentations in "Quanto è fiero il mio tormento," and "Cara negl'occhi tuoi" reveals the embellishments of the former aria to be more preposterously ostentatious than those of the latter aria. Although we don't have records of his embellishments in the interim period, one could speculate that his age and status as had something to do with it. When he performed "Quanto è fiero" in 1784 he was 29 years old and sought to establish himself and to show off his technical capabilities. In contrast, he was a famous thirty-seven-year-old when he performed Pirro's arias. Furthermore, it cannot be discounted that by 1792 his voice was beginning to show signs of decline. However, there is a common denominator in his ornamentation method between both examples. Each began with tasteful and elegant embellishments enhancing the original line but subsequently transform into a display of sheer virtuosity. 
In the slow sections a phrase could be made up using as many as three types of ornamented ideas. "Mm. 25-29 and 35-38, variation 1 of Cara negl'occhi tuoi," feature three types of figurations, while variations 2 (dotted rhythm) and 4 (a turn and a dotted rhythm) employ a sole embellishment idea (see example 3).

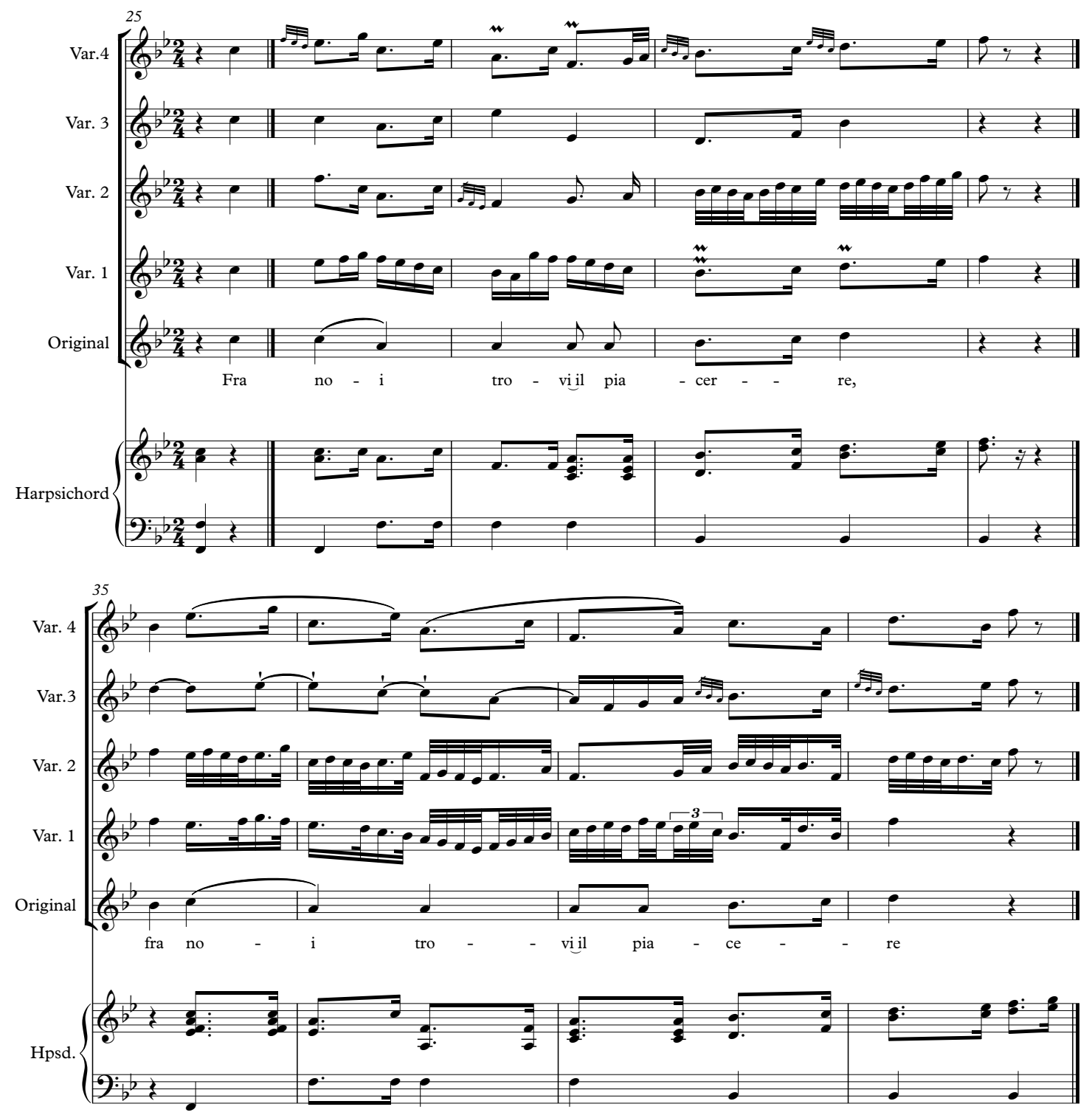

Example 3: Pichl's renditions of Marchesi performing mm. 25-28 and 35-38 of Zingarelli's aria "Cara negl' occhi tuoi," from the opera pirro re d'Epiro, based on Ms. Bc. 11550. The example shows that Marchesi embellishments in variation 3 and 4 are homogenous and diverse in variations 1 and 2.

In some instances, Marchesi's embellishments do not enhance the composition, and the excessive embellishments do injustices to the original line. For instance, in measure 20 of Cherubini's rondo, the first two variations enhance the original melodic line, while the instrumental diminution in variations 5-7 sound like instrumental cadenzas lacking any semblance of grace (see examples 2a and 2b).

In contrast, in measures 24-41 of Pirro's aria, the embellishments enhance the drama taking place on stage. According to Gemorra's stage directions, the band is instructed to interrupt Pirro's love aria by 
marching onto the stage. ${ }^{46}$ Both the orchestral part and Zingarelli's original vocal line feature the dotted rhythm typical of the march and the tempo marking changes to Marcia; Marchesi's embellishments create a clash between the vocal part and the orchestra-between Ulysses (portrayed by the marching band on stage) and Pirro (see example 4$){ }^{47}$

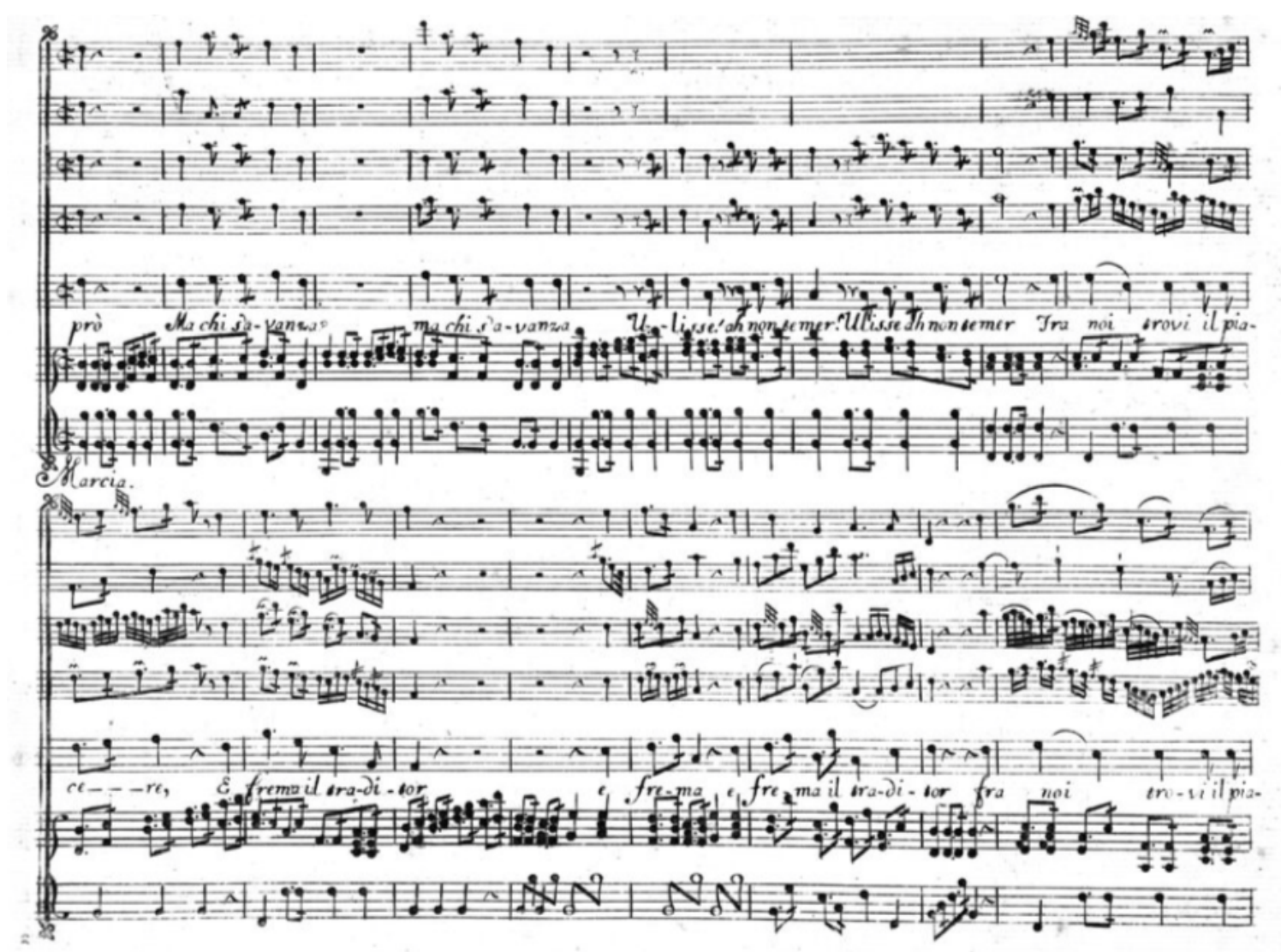

Example 4: "Cara negl'occhi tuoi," measures 26-34. Ms. Bc 11550. Performed by Ann Hallenberg with Stile Galante, conducted by Stefano Aresi

Listen at: http://dx.doi.org/10.3998/mp.9460447.0010.203

Marchesi's variations are inconsistent in the manner and degree to which melodic contour and structure are preserved. In some cases, he retains the contour of the melody or, at least, a salient feature of the melody, while, in other instances the melody is entirely disregarded. For instance, the melodic structure of mm. 74-77 of "Cara negl'occhi tuoi" is a two-measure motif (measures 74-75), which is repeated in measures 76-77, creating two disjointed melodic units. In variations 2 , 3, and 4 the embellishments follow the original key and preserve the contour of the melody, although he varies the embellishments in the repetition. In contrast, m. 73, V. 3 the melody tonicizes c minor, and the motif and its repetition are combined to form a single phrase. In mm. 14-17 of the same aria, despite extensive decoration, the sequential component of the melody is preserved intact (see example 5).

\footnotetext{
${ }^{46}$ Giovanni de Gamerra, Pirro, Re di Epiro; dramma per musica da rappresentarsi nel teatro alla Scala il carnevale dell' anno 1792 , p. 54 .

${ }^{47}$ I thank Stefano Aresi for bringing this point to my attention.
} 

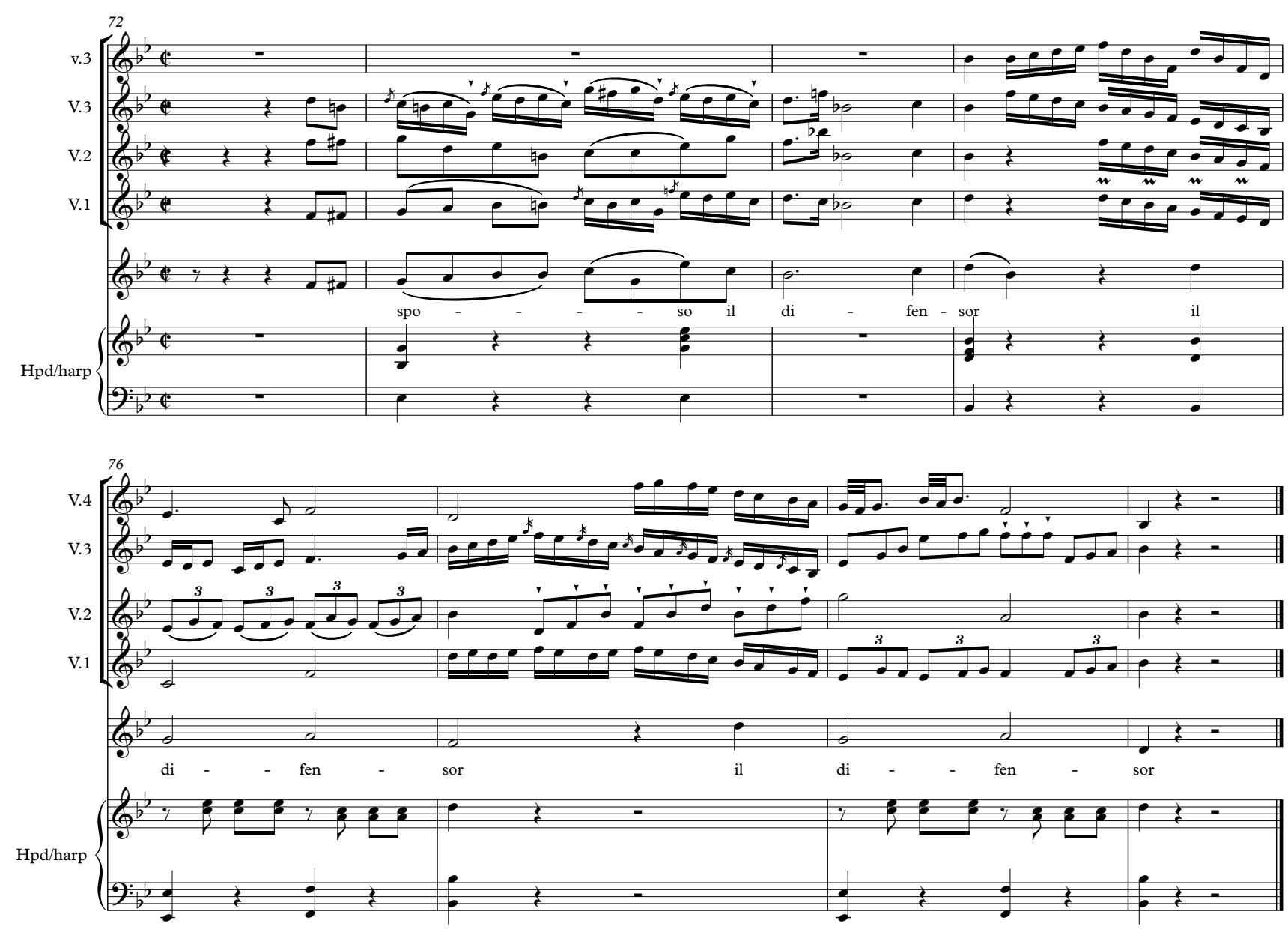

Example 5: Zingarelli's "Cara negl'occhi tuoni," measures 72-79 with Marchesi's variations as notated by Pichl in Milano in 1792. Based on Ms. B-BC 11550. Performed by Ann Hallenberg with Stile Galante, conducted by Stefano Aresi

Listen to Var. 1 at: http://dx.doi.org/10.3998/mp.9460447.0010.203

Another example that shows his inconsistency is in mm. 59-60 of Cherubini's rondo, where Marchesi retains the melodic contour in all the variations except for in V. 3, m. 59. Note the identical embellishment applied to the sequential units in V.8 (see example 6).

Marchesi ornamented the simple melody in two ways. In one approach he encompasses the notated melodic pitch with turns, appoggiaturas, trills, mordents, and grace notes (see, for example, the embellishment on the $\mathrm{Bb}$ in variation 1). The second approach is to articulate the melody's underlying harmony by limiting his embellishments to chord tones (for example, the arpeggiation of the Eb major triad in measure 9 of variation 4, and in measure 23 of variation 9 in Cherubini's score). Occasionally, (as in measure seven of Zingarelli's aria), the root and seventh of the implied chord are added (see example 7).

Large melodic skips in the score are ornamented either by filling in the interval with a variety of figurations, or by exaggerating the notated disjunction with an even wider interval. In measures 22-23 of "Quanto è fiero," there is a skip of an octave in the original melody. In all of the variations he expands the interval from a fourth below the melodic pitch to a fifth above $\left(A^{3}-A^{5}\right)$. In variation 4 , he applies an arpeggiated $\mathrm{d}$ minor triad interrupted by rests. In variations 7 and 9 he fills in the intervals with an 
ascending chromatic scale; and in variations 5 and 8 the octaves are filled in with a melodic sequence. This is yet another example wherein Marchesi's embellishments seem more like an instrumental cadenza than a heartfelt depiction of the words sento l'alma [I feel my soul]. (See example 8.)
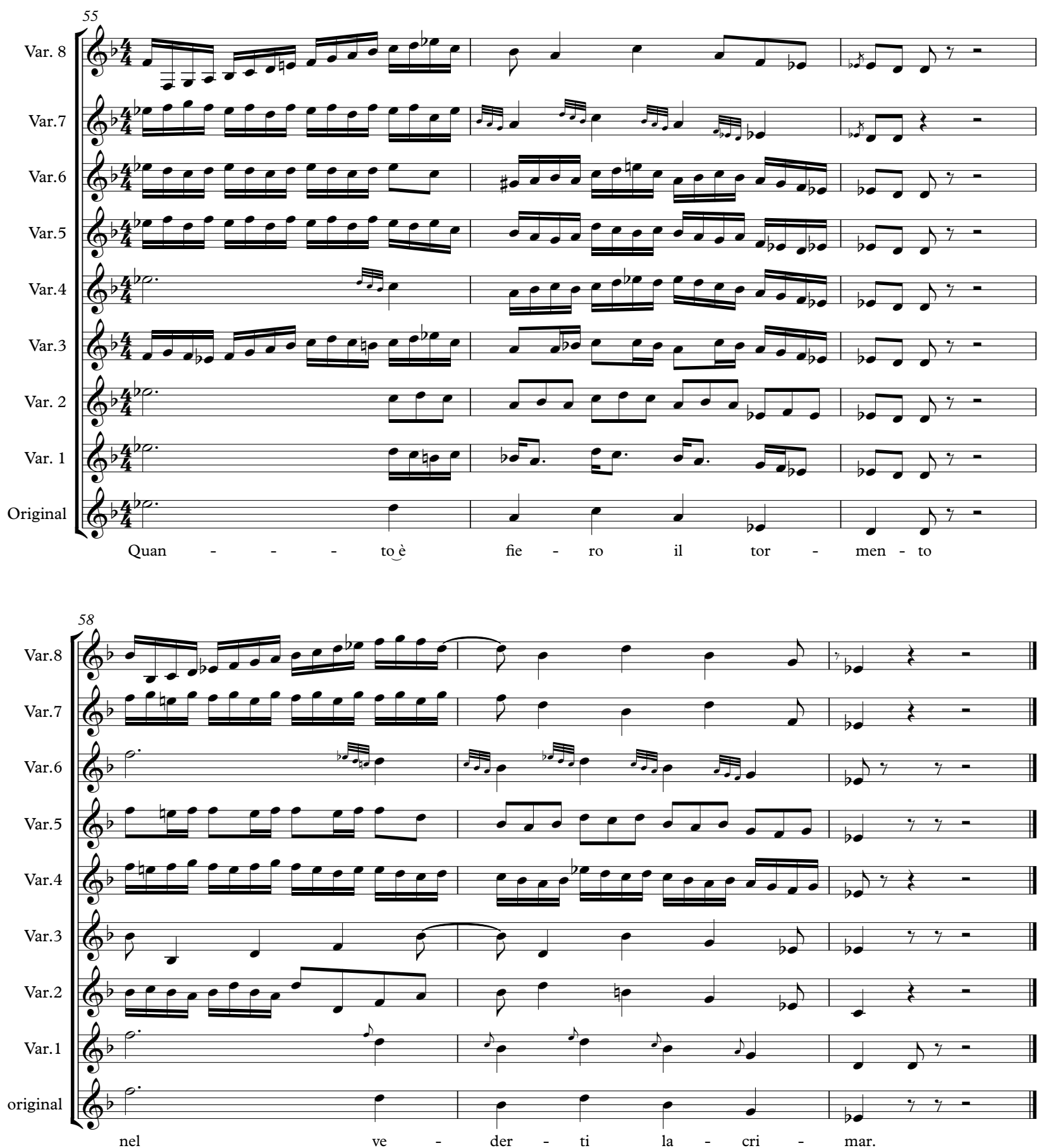

Example 6: Measures 55-60 of Cherubini's aria "Quanto è fiero il mio tormento" 


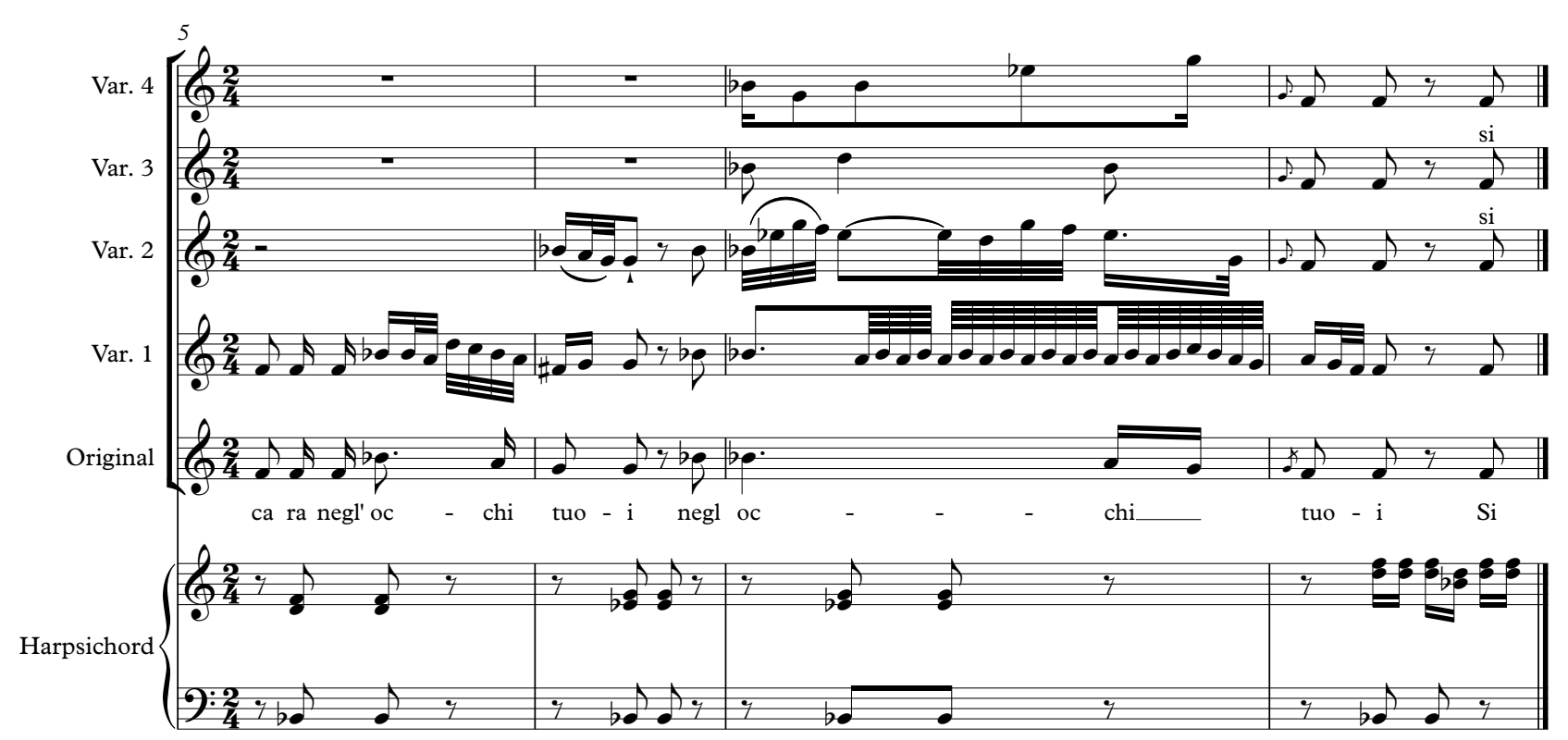

Example 7: Measures 5-8 of Niccolò Zingarelli's aria "Cara negll'occhi tuoi," from the opera Pirro re d'Epiro. Performed by Ann Hallenberg with Stile Galante, conducted by Stefano Aresi

Listen to Var. 1 at: http://dx.doi.org/10.3998/mp.9460447.0010.203

Based on the renditions, Marchesi's adherence and allegiance to the text was inconsistent as well. While often prone to entirely disregarding the meaning of the text in lieu of vocal pyrotechnics, he does, at key moments, underscore the meaning of the text through particular embellishments. Zingarelli set the words "sposo Il defensor" [your spouse is your defender] (measures 76-78) of "Cara negl'occhi tuoi" in a very simple melodic line in half note values, and a strong intervallic motion combining stepwise motion and skips of a third and a fifth, which convey power and strength. The motif repeats twice with a small variant at the end of the repetition. This simple melodic line was transformed in four different ways by Marchesi, from simple (variation 1) to highly embellished lines (variations 2-4). The embellishments obscure and weaken both the text and the melodic structure. In this instance, Marchesi did not create a correspondence between the meaning of the text and his embellishments (see example 9.) In contrast, in mm. 9-16 of Zingarelli's aria, the text "si pasce il mio desire" [my desire is being nourished], which is also repeated twice, the embellishments express the word "si pasce." The ascending Bb major scale highlights the repetition of the word "pasce" and the diminished interval of a fourth (see example 9).

Measures 28-36, of "Cara negl'occhi tuoi," provide another example in which the meaning of the text is supported. Zingarelli's sets the text "Fra noi trovi il piacere" [Amongst us you could find pleasure], with a rather banal march-like pattern of dotted rhythms. Marchesi made the melody far more interesting and coherent by elaborating the repetition of the motif (see example 3 ). 

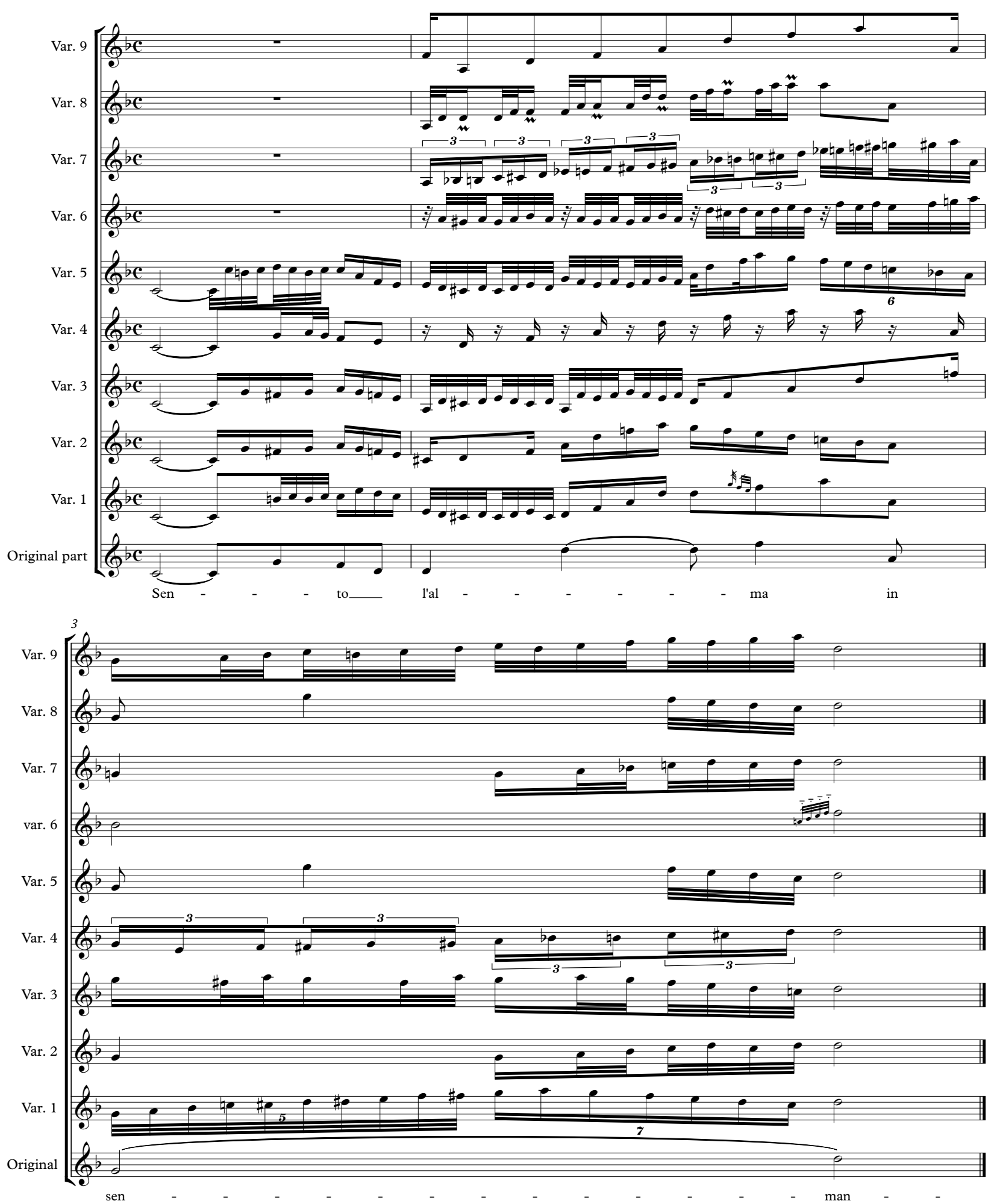

Example 8: Cherubini's Rondo "Quanto è fiero il mio tormento," measures 23-24 based on the manuscript in Paris. Cherubini's melodic line comprises disjunt intervals. Marchesi fills in the gaps in a variety of figurations. Variations 2, 6, 8, and 9 are based on an arppegiated D minor triad. Variation 7 is based on an ascending chromatic scale. 


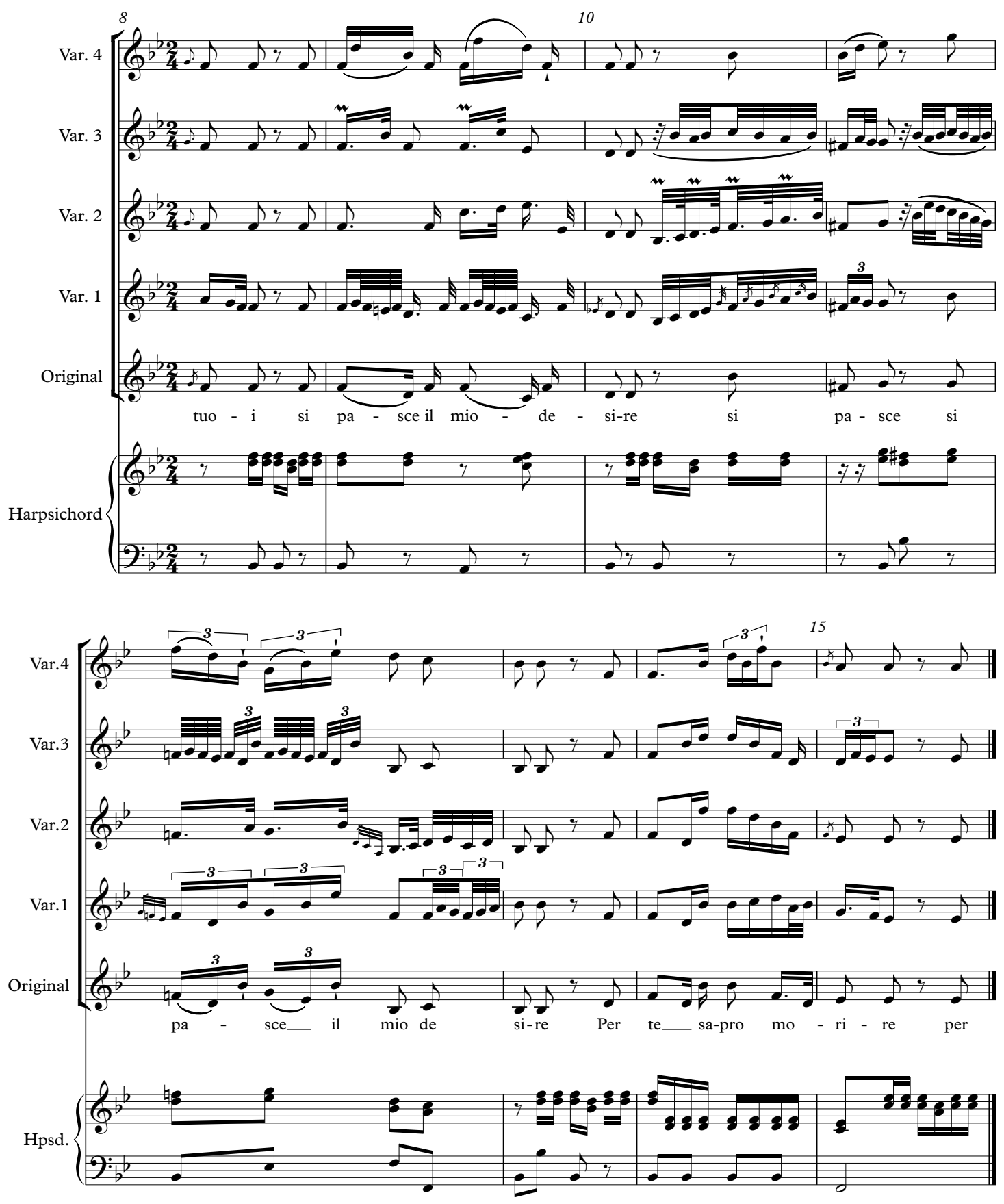

Example 9: Measures 9-16 of "Cara negl'occhi tuoi." Marchesi colored the text "si pasce il mio desire" with his ornate embellishments. Performed by Ann Hallenberg with Stile Galante, conducted by Stefano Aresi

Listen to Var. 1 at: http://dx.doi.org/10.3998/mp.9460447.0010.203

\section{The Effect of the Virtuoso Castrato on Western Vocal Tradition}

During the eighteenth and early nineteenth centuries female sopranos were creating the role of the hero or heroine. ${ }^{48}$ When a castrato was unavailable to create the hero role, it was created by travesti, female

${ }^{48}$ Naomi André, Voicing Gender: Castrati, Travesti, and the Second Woman in Early-Nineteenth-Century Italian Opera (Indiana 
sopranos sporting pants and singing male roles (for example, Guiditta Pasta, Maria Malibran, and Anna Davia De Bernucci. De Bernucci sang the role of Pirro in Firenze in 1792. The libretto title page reads: nel regio Teatro degli Intrepidi detto della Palla a corda nella primavera dell'anno 1792). ${ }^{49}$

Female sopranos imitated the castrati virtuosic singing when singing the hero or heroine role. As Susan Staves states, they "challenged the castrati monopoly on brilliant singing and demonstrated a female capacity for learned musicianship."

The following anecdote about Nancy Storace imitating "La bomba di Marchesi" was described by Michael Kelly in 1822:

"In the performance of Bianchi's cavatina "Sembianza amabil del sole" which Marchesi sung with the most ravishing taste; in one passage he ran up a Valetta of semitone octaves, the last note of which he gave with such exquisite power and strength, that it was ever after called "La bomba di Marchesi." Immediately after this song Storace had to sing one, as was determined to show that she could bring a bomba into the field also." ${ }^{51}$

Divas were criticized in the same manner as was Marchesi and other castrati, as evident in Metastasio's critical review of Gabrielli's cadenzas: "If the wondrous Gabrielli doesn't have a melisma thirty measures long and doesn't go up to high e the spectators freeze. She could warm them more by singing to the heart, but to do so she would have to find a new method." 52

Lord Mount Edgcumbe disapproved of Angelica Catalani’s excessive ornamentations:

Her voice is of a most uncommon quality, and capable of exertions almost supernatural [...] while its agility in division, running up and down the scale in semi-tones and its compass in jumping over two octaves at once are equally astonishing.

It were to be wished that she were less lavish in display of these wonderful powers, and sought to please more then surprise; but her taste is vicious, her excessive love of ornaments spoiling every simple air. ${ }^{53}$

After the golden age of the castrati the hero role first carried by travesti, was transferred to contralto and tenor voices, which assumed the virtuosic role and replaced the travesti. ${ }^{54}$ Virtuosic singing remained part of the soprano voice now performed by a female in the capacity of singing a female role. The heroine role was sung by a high soprano, and the hero role by a mezzo-soprano. The castrato technique and singing style was adapted to other vocal types. ${ }^{55}$ Vocal pedagogy continued to emphasize virtuosity and focus on embellishing variations. Marchesi's singing style became a model for virtuoso soprano vocalization. The publication of Cherubini's rondo, a decade after it was first performed under the title "Etude," demonstrates this point.

As noted earlier, Marchesi's singing style had an impact on fortepiano pedagogy. The renowned pianist and pedagogue Hélène Montgeroult demonstrated cantabile keyboard style using Marchesi's

University Press, 2006), 89.

${ }^{49}$ Biblioteca nazionale central (Firenze, 3.)

${ }^{50}$ Susan Staves, “The learned female soprano," Bluestockings Displayed. Ed. Elizabeth Eger. 1st ed. Cambridge: Cambridge

University Press, 2013, 141-63. Cambridge Books Online. Accessed November 25, 2014.

http://dx.doi.org/10.1017/CBO9780511667428.010.

${ }^{51}$ Michael Kelly, Reminiscences of Michael Kelly, of the King's Theatre, and Theatre Royal Drury Lane (1825) (Cambridge

University Press, 2011), 98.

${ }^{52}$ Feldman, "Denaturing the Castrati," 187.

${ }^{53}$ Richard Edgcumbe in Musical Reminiscences of an Old Amateur (London: W. Clarke, New Bond Street, 182), p. 553.

${ }^{54}$ André, Voicing Gender, 4, 37-43.

${ }^{55}$ Ibid., 37 and 43. 
ornamentations in "Cara negl'occhi tuoi" in her method book for fortepiano Cours complet pour l'enseignement $d u$ forté piano. ${ }^{56}$ (See Examples 10a and 10b.) Although not credited in her publication, the ornamentation is an almost verbatim replication of Pichl's transcription. (Minor differences are found in lines 2-4 of measures 5-6, in which Montgeroult provides ornamentation and suggested fingerings where Pichl's score is absent of ornamentation.) Montgeroult's beaming is identical to Pichl's publication, although there is some variance in phrase markings.

Montgeroult assigned the accompaniment to the left hand with the instruction that it be performed in strict time; the vocal part is assigned to the right hand, which has to imitate the singing voice by playing freely in cantabile style with rubato. ${ }^{57}$

She writes:

I give here a model that will be the subject of an important study for the student. Marchesi is the most famous singer for the breadth and variety of his taste. He himself notated the four different ways which he sang the scene found below [...] and this is the place to recall that absolute necessity of having such independence between the two hands that the left maintains the beat strictly, while the right hand, like the singer, broadly traverses the melodic phrase without speeding it up so as to finish with the beat, imitating as much as possible the accents and nuances that the singing voice would give to it. It is in this way only that he can hope to approach the breadth of expression and style that distinguishes the great singers. ${ }^{58}$

Baron de Trémont, who was a close friend of Montgeroult, describes her teaching method:

She made a particular study of phrasing like the great singers of Italy; Marchesi, Crescentini, etc. The singing phrase was expressed in conformity with the breathing of the singer [...] The artist must therefore achieve the binding together of notes $[\ldots]$ and prolong and nuance the sound as if it were produced by a bow or by the breath. Then it [...] will sing, which is the essential goal of music. None of her pianist contemporaries applied this principle as she did; none had such a great volume of sound, or played the adagio with such profound expression.

In reaction to the excesses in vocal acrobatics that disfigured the original music, composers, including Rossini and Donizetti, assumed greater control over their music, wresting much of the vocalists' improvisatory freedom, and restricting their unbounded excursions in cadenzas.

Rossini writes:

This mode of singing violin concertos and variations without end tends to destroy not only the talent of the singer, but also to vitiate the taste of the public. Every singer will make a point of imitating Velluti, without calculating upon the relative compass of his voice. We shall see no more simple Cantilenas; they would appear cold and tasteless [...] My mind is set. I will not leave them room for a single appoggiatura. These ornaments, this method of charming every ear, shall form an integral part of my song, and shall be written down in my score. ${ }^{59}$

Along with composers' "reining in" of excessive improvisation, fascination with extreme virtuosity and extended vocal technique persisted. Philip Brett describes the role of the tenor in Benjamin Britten's $A$ Midsummer Night's Dream (1960), as "Far from the ardent tenor of the Romantic era and close one can get to of the eighteenth-century opera seria, the castrato the primo nomo." 60

\footnotetext{
${ }^{56}$ I am grateful to the Stanford Music Library for assisting me in obtaining the reproduction facsimiles of Hélène Montgeroult, Cours complet pour l'enseignement du forté piano.

${ }^{57}$ Hélène Montgeroult, Cours complet pour l'enseignement du forté piano, Premiere Partie (Janter \& Cotelle, Paris, 1826), 234-35.

${ }^{58}$ Cited and translated by Stephanie Lynn Frakes in Chopin's Cantabile in Context (The Ohio State University, 2013 ), 108.

${ }^{59}$ New Monthly Magazine (Henry Colburn,1833), 205.

${ }^{60}$ Philip Purvis, Masculinity in the Opera (Routledge Research in Music, 2013), 44.
} 
234

J'ai déja dit que les ornemens particuliers au mécanisme de chaque instrument n'étant pas toujours de bon goût, ce n'est qu'en essayant d'imiter la voix dans les Appoggiatures, comme dans toute espèce de chant, que l'on approchera du mieux possible.

Je donne ici un modele qui sera pour l'éléve le sujet d'une importante étude. MARCHESI, est le chanteur le plus célébre pour l'étendue et la variété de son goût. Il a lui même noté les quatre manières différentes dont il chantait la scène qu'on trouve ci-après. Les accompagnemens en ont été réduits pour la seule màin gauche, afin que l'éléve pût étudier de la droite les variantes du chant de ce morceau. Il y verra que le talent du chanteur faisait tout le succes de, cette scène qui n'est par elle-même qu' un simple canevas; et il y pourra prendre une idée de la manière de placer les Appoggiatures: mais qu'il se garde bien de donner à ces ornemens le brillant d'un trait de Concerto; il dénaturerait entièrement le caractere de chaque morceau, et en ferait toujours de la musique d'exécution. Il faudra donc que, de la main droite, il anticipe d'une mesure sur l'autre, afin de ne pas presser les traits contenus dans une seule, et c'est ici le lieu de rappeler cette absolue necessité d'avoir une telle indépendance entre les deux mains, que la gauche maintienne rigoureusement la mesure, tandis que la droite, ainsi que le chanteur, parcourt largement la phrase chantante, sans la precipiter pour la finir avec la mesure, et en imitant le plus possible les accens et les nuances que la voix lui donnerait. c'est ainsi, seulement, qu'il peut espérer d'approcher de la largeur d'expression et de style qui distingue les grands chanteurs.

A R I A

del signor

Z 1 NG A R ELLI,

Con Variazioni

del signor

Marches I.

Ritournelle.

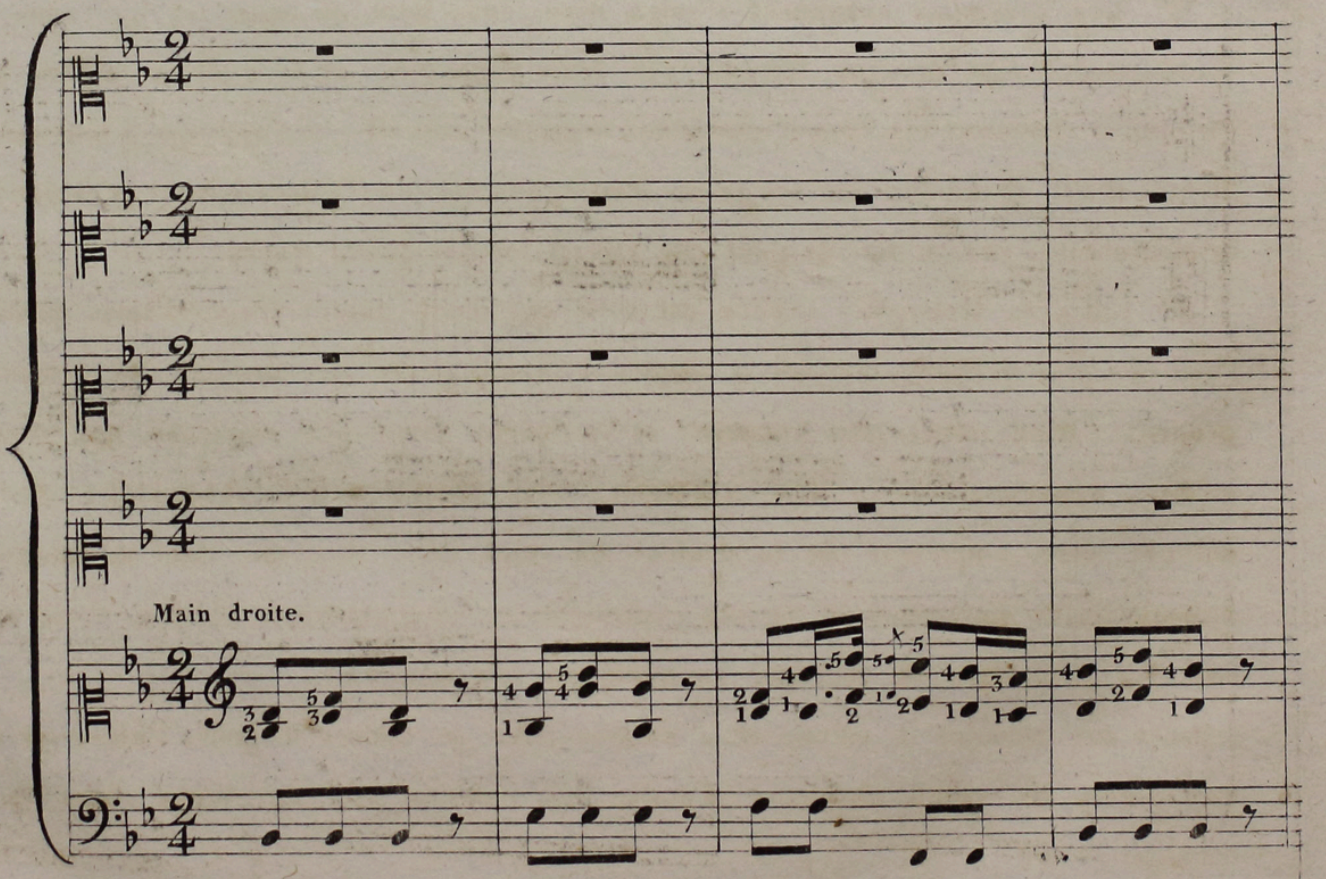

17 e. S.

1.P.

Example 10a: Page 234 of Hélène Montgeroult's Cours complet pour l'enseignement du forté piano 


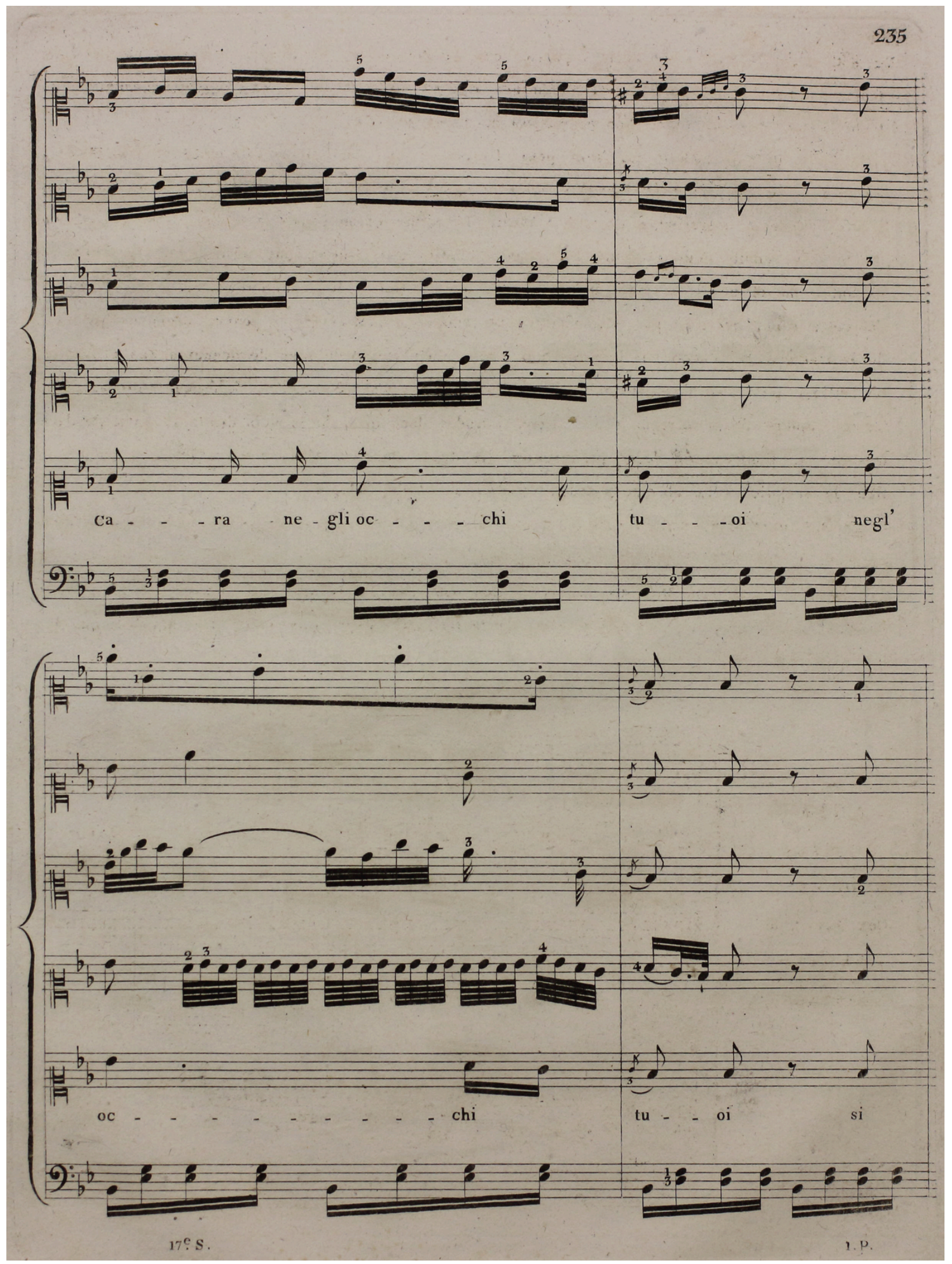

Example 10b: Page 235 of Hélène Montgeroult's Cours complet pour l'enseignement du forté piano 
In the second half of the twentieth century, avant-garde composers and performers sought ways to extend traditional vocal techniques. This inspired a resurgence, or more precisely, a redefinition of virtuosity. Singers such as Cathy Berberian, Joan La Barbara, Diamanda Galas, and others became the legacy of the extreme vocal range and agility of the great castrati like Marchesi. As in the age of the castrati, composers often wrote specifically for the voice of a particular singer, creating a showcase for that voice and relying upon their particular styles and characteristics of extemporization. Berberian's extraordinary vocal ability inspired, among others, Berio, Milhaud, Cage, and Haubenstock-Ramati.

Many scores, particularly those of Haubenstock-Ramati, Cage, and Berberian, were graphic and reliant upon the performer's extemporization.

In summary, Pichl's rare and unique transcriptions recorded those aspects of the historical voice of the superstar castrato singer Luigi Marchesi that could be captured and represented in conventional music notation. They confirm period accounts of his singing style: his vocal agility, his excessively embellished style, and the degree to which he departed from the original scores. It appears that at least in the case of Pirro's arias, the performances were a product of collaboration between composer and performer, since Zingarelli approved Pichl's transcriptions. Zingarelli provided a simple melodic outline inviting ornamentations; the final version was extemporized on the fly by Marchesi during the performances and varied from one performance to the next.

A comparison between the original scores of Cherubini and Zingarelli and Pichl's renditions shows inconsistencies in Marchesi's choices of ornamentation. There are instances in which Marchesi adhered to the structure of the original melody, while in others he disregarded it. In several cases, his embellishments elegantly decorated the original line, and enhanced the dramatic flow. In others, they hampered it because they took the focus away from the music and the text, and shined the light on Marchesi's supernatural technique.

Fortunately, the fascination and interests of the group of music dilettantes gave a reason to create these "recordings" - whether as commemorative "keepsakes" or as functional records to be imitated and replicated.

\footnotetext{
Abstract

In the Milanese carnival of 1792, the virtuoso castrato Luigi Marchesi (1754-1829) performed Niccolo Antonio Zingarelli's opera Piro re d'Epiro, in which, as was the custom, he richly elaborated Zingarelli's simple melodic lines. Four renditions of the aria "Cara negl'occhi" and the rondo "Chi mi da consiglio," performed on four different nights, were transcribed by the composer Václav Pichl. These transcriptions-essentially performance recordings from the 18th century_offer a unique and remarkable document of castrato singing, in particular Marchesi's extraordinary ability.

In this essay, I analyze Pichl's transcriptions of Marchesi's vocal acrobatic display_virtuosity and technique due in part to 'natural gift' and in part to the unnatural physiological intervention of castration. The essay compares each variation and provides an analysis contextualized by historical performance practices and by specific analysis of the music and text that provided the basis for Marchesi's extraordinary vocal pyrotechnics.
} 